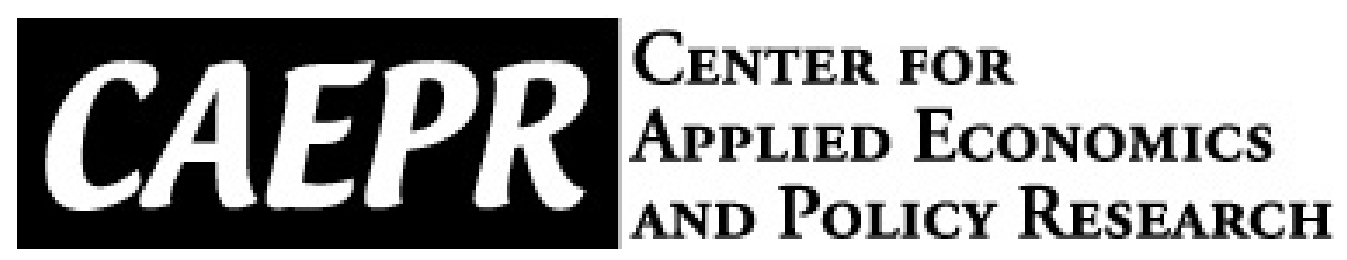

CAEPR Working Paper

\#015-2009

\title{
ANCHORING FISCAL EXPECTATIONS
}

\author{
Eric M. Leeper \\ Indiana University
}

August 16, 2009

This paper can be downloaded without charge from the Social Science Research Network electronic library at: http://ssrn.com/abstract=1456393.

The Center for Applied Economics and Policy Research resides in the Department of Economics at Indiana University Bloomington. CAEPR can be found on the Internet at: http://www.indiana.edu/ caepr. CAEPR can be reached via email at caepr@indiana.edu or via phone at 812-855-4050.

(C)2008 by NAME. All rights reserved. Short sections of text, not to exceed two paragraphs, may be quoted without explicit permission provided that full credit, including $\odot$ notice, is given to the source. 


\title{
ANCHORING FISCAL EXPECTATIONS
}

\author{
ERIC M. LEEPER
}

\begin{abstract}
In this lecture, I argue that there are remarkable parallels between how monetary and fiscal policies operate on the macro economy and that these parallels are sufficient to lead us to think about transforming fiscal policy and fiscal institutions as many countries have transformed monetary policy and monetary institutions. Making fiscal transparency comparable to monetary transparency requires fiscal authorities to discuss future possible fiscal policies explicitly. Enhanced fiscal transparency can help anchor expectations of fiscal policy and make fiscal actions more predictable and effective. As advanced economies move into a prolonged period of heightened fiscal activity, anchoring fiscal expectations will become an increasingly important aspect of macroeconomic policy.
\end{abstract}

\section{INTRODUCTION}

A stunning transformation in monetary policy has occurred in the past 15 years. Central banks have moved from "monetary mystique" to a "culture of clarity," a movement in which the Reserve Bank of New Zealand has led the way. It is now widely accepted that for monetary policy to effectively stabilize the real economy and inflation, it should be guided by several principles: monetary policy should be independent of fiscal policy, insulated from political pressures, and avoid fooling people in order to offset the dynamic effects of distortions in the economy; in addition, central bankers should communicate transparently about their objectives and their strategies for achieving those objectives and they should be held accountable for their decisions.

Date: August 16, 2009. Department of Economics, Indiana University; eleeper@indiana.edu. Forthcoming in Reserve Bank of New Zealand Bulletin. This paper draws on the author's public lecture on November 12, 2008 in Wellington, New Zealand, which was part of the author's tenure as a Professorial Fellow in Monetary and Financial Economics at Victoria University of Wellington and the Reserve Bank of New Zealand. I thank the Victoria University of Wellington Foundation, the Victoria University of Wellington School of Economics and Finance, and the RBNZ for their fabulous hospitality to me and my family and for providing me with this unusual intellectual opportunity. Many people provided useful input to this lecture, particularly, Mark Blackmore, Stephen Burnell, Peter Bushnell, Arthur Grimes, Viv Hall, John Janssen, John McDermott, Adrian Orr, and Bryce Wilkinson. I also thank Huixin Bi, Troy Davig, Jim Poterba, and Shu-Chun Susan Yang for comments on this draft.

JEL codes: E52, E63, H60.

Keywords: monetary-fiscal policy interactions, sustainability, transparency. 
There is less widespread agreement about the position taken by some central banks to take transparency to the next level by announcing the governors' own views about the likely future path of the policy interest rate. ${ }^{1}$

Still more remarkable is that this transformation occurred in the absence of any real evidence that transparency of monetary policy and improved communication by central banks actually matter for the performance of the economy. ${ }^{2}$ Two conditions drove the move toward greater transparency. First, a professional consensus emerged that inflation is a monetary phenomenon and that inflation control is the appropriate purview of the central bank. Second, and perhaps more important, a political consensus developed that low and stable inflation is desirable because inflation fluctuations redistribute wealth in capricious ways [Faust and Henderson (2004)]. It took several decades of poor macroeconomic performance for these consensuses to develop.

Why have we seen no corresponding enlightenment in governments' tax and spending policies? Despite a range of changes in fiscal frameworks across advanced countries since the 1990s, in general, fiscal policy remains as opaque as ever. Is it desirable to transform fiscal policy in a manner that is analogous to what has occurred with monetary policy? Is it feasible? Can professional and political consensuses on the effects and role of fiscal policies be reached?

Monetary authorities and fiscal authorities appear to mean different things by "transparency." For central banks it is a means to an end: the better the public understands and anticipates monetary policy choices, the more firmly expectations will be anchored on actual monetary policy goals, and the more effective monetary policy will be in achieving its objectives. This is the sense in which I shall use the term. But this is not how fiscal authorities apply the term. In fiscal realms, "transparency" means the adoption of generally accepted accounting principles, the conduct of policy in an open and public way, and so forth. Fiscal transparency is more about establishing the integrity of the fiscal process than it is about helping the public to form expectations of future tax and spending policies. Although fiscal authorities compute and publish fiscal projections, the projections typically condition on current policies; they are silent on possible future policies and, therefore, contribute little to transparency and the anchoring of fiscal expectations.

This lecture will argue that there are strong parallels between how monetary and fiscal policies affect private-sector behavior and what the two kinds of policies can achieve in the macro economy. Along many important dimensions monetary and fiscal policies have more similarities than dissimilarities. As a consequence, the arguments that have led countries to make dramatic reforms to their monetary policy

\footnotetext{
${ }^{1}$ Faust and Leeper (2005) discuss these issues in more detail in the context of monetary policy.

${ }^{2}$ There is now evidence supporting the earlier presumption [see Blinder, Ehrmann, Fratzscher, De Haan, and Jansen (2008)].
} 
institutions apply with equal - or possibly greater - force to fiscal policy. Because fiscal policy actions typically generate changes in government debt, taxes, and spending that extend over several decades, in practice, dynamics may be more important for fiscal policy than for monetary policy [Chung and Leeper (2007), Leeper, Plante, and Traum (2009)].

This fact has not been fully embraced by institutional reformers. ${ }^{3}$ Instead, fiscal reforms are often superficial and frequently ineffectual when compared to the thorough-going reformations of monetary policy in many countries. I will argue that this asymmetric treatment of monetary and fiscal policies runs the risk of undermining the progress made in monetary policy. I will also argue that, because fiscal policy in many countries is likely to raise substantial economic and political challenges over the next several decades, fiscal transparency and the anchoring of fiscal expectations will become increasingly important aspects of macroeconomic policy. Effective reforms may require statutory or constitutional enforcement that give the reforms bite.

Inconsistencies between monetary and fiscal policy frameworks are most likely to become apparent in times of economic stress. The current financial turmoil and worldwide recession may provide a challenging test to the monetary-only reforms.

\section{Fiscal Failure Breeds Monetary Success}

2.1. Fiscal Roots of Extreme Crises. History abounds with examples where badly managed fiscal policies undermined the ability of monetary policy to achieve its macroeconomic objectives. Even observers who subscribe to the adage that "inflation is always and everywhere a monetary phenomenon," acknowledge that it is "almost always" and "nearly everywhere." Hyperinflation is the classic exceptionpresumably the one that makes the rule - of an inflation whose fundamental cause is fiscal policy run amok.

The best-known hyperinflation occurred between the world wars in Europe. After World War I, Germany was under tremendous fiscal strain: the Versailles Treaty entailed substantial reparation payments from Germany to France and England; the German government was trying to rebuild an economy destroyed by war; the destroyed economy created an extraordinarily weak tax base, making it impossible to collect sufficient revenues to cover expenditures. Government budget deficits were large, with revenues never covering more than about 35 percent of expenditures. Running the printing presses was the only fiscal option available to the government, with the predictable results. Between July and November of 1923, the inflation rate was 560

\footnotetext{
${ }^{3}$ Although many treasuries or other fiscal agencies are required to construct long-term projections, for reasons discussed below, these projections do not adequately reflect the dynamics of fiscal policies; neither do they contribute toward making fiscal policy meaningfully more transparent.
} 
billion percent. Figure 1 records the overall price level in Germany from 1919 to 1924, using a logarithmic scale. During this period, the price level increased several trillion fold. ${ }^{4}$

Germany's hyperinflation led after World War II to the Bundesbank's singular success in controlling inflation. Germany's Bundesbank was widely regarded as the world's foremost inflation fighter, even during the 1970s when many countries experienced a steady upward march in inflation rates. Even now hyperinflation's legacy looms large over European monetary policy: European Monetary Union, with Germany as a central player, is designed to carry the legacy of the horrors of hyperinflation into policy decisions of the European Central Bank.

Latin American countries are well known for having high inflation or periodic bouts of hyperinflations in which fiscal policies have played a central role [Singh, Belaisch, Collyns, De Masi, Krieger, Meredith, and Rennhack (2005)]. Some examples of peak inflation rates are: Bolivia, May to August 1985, 60,000 percent [Sachs (1987)]; Argentina, May 1989 to March 1990, 20,266 percent [Reinhart and Savastano (2003)]; Peru, July to August 1990, 12,378 percent [Reinhart and Savastano (2003)]. Chile became the world's second inflation targeting country when it transformed its monetary policy in September 1990. Five other Latin American countries-Brazil, Columbia, Mexico, and Peru - now officially target inflation [Vega and Winkelried (2005)]. Several of these countries, and Chile in particular, backed up their monetary reforms with dramatic fiscal reforms.

2.2. Fiscal Role in Moderate Crises. Sweden and New Zealand are instructive examples of countries that experienced moderate - judged by the standards of hyperinflations - economic crises to which the macroeconomic policy response was reform of both monetary and fiscal institutions. Both countries also underwent extensive deregulation of financial markets immediately preceding the macroeconomic reforms. Although both countries did adopt fiscal reforms, those reforms were not nearly as through-going as the monetary changes, which were wholesale reforms of the objectives and the execution of monetary policy.

2.2.1. Sweden. In the early 1990s Sweden experienced a boom-bust cycle that severely tested the prevailing monetary-fiscal policy regime. ${ }^{5}$ After deregulation of the financial system, the economy boomed in the late 1980s, with rapid growth in GDP,

\footnotetext{
${ }^{4}$ Of course, along with the massive inflation came large distortions to the real economy and the associated output losses. Sargent (1986) describes several other historical episodes of hyperinflation at the same time-Austria, Hungary, and Poland - tracing each to large-scale fiscal failures.

${ }^{5}$ This section draws liberally from Swedish Ministry of Finance (2001), Jonung (2009), and Wetterberg (2009).
} 
employment, consumption, and imports. Despite a worsening current account balance, monetary policy was prevented from reacting to the boom because the krona was pegged to a basket of currencies.

By 1989-1990 the boom had ended and the bust began. Rising international real interest rates exerted further pressure on the pegged krona while simultaneously the Riksbank raised nominal interest rates to defend the krona against speculative attacks. Major tax reform in 1990-1991 sharply lowered marginal tax rates and reduced mortgage deductibility, raising real after-tax interest rates still more. The strong increases in real rates deflated asset values, which reduced wealth and triggered a banking crisis.

The resulting recession was comparable to Sweden's experience in the Great Depression. GDP fell for three consecutive years. Unemployment rose from 1.5 percent in 1989 to over 8 percent in 1993. The cumulative employment loss exceeded that of the Great Depression, according to Jonung (2009). Attacks on the krona continued, culminating in the famous instance on September 16, 1992 when the Riksbank raised the overnight rate to 500 percent. ${ }^{6}$ In the event, by November 19 the Riksbank allowed the krona to float.

Large automatic stabilizers built into Swedish fiscal rules swung the general government balance from a 5 percent surplus in 1989 to nearly a 12 percent deficit in 1993. ${ }^{7}$ Central government debt rose from 30 percent to 80 percent of GDP over the same period.

The Swedish government responded with a thorough reform of both monetary and fiscal policy. Beginning in January 1993, the Riksbank announced a 2 percent target for CPI inflation, applying from 1995 on. This target was formalized by the Sveriges Riksbank Act, passed in 1997, an act that greatly reinforced the Riksbank's independence [Sveriges Riksbank (2008)]. Fiscal policy in 1993 consolidated in fits and starts, but projections showed government debt continuing to grow rapidly and fears of sustainability arose. Progress on fiscal reform was motivated by at least three concerns. First, bond markets downgraded Swedish sovereign debt in 1993. Second, by the end of 1993 one-third of government expenditures were devoted to debt service. Third, it was recognized that fiscal instability could undermine the Riksbank's newly adopted inflation targeting regime. A series of bills beginning in late 1994, called the "Consolidation Programme," sought to stabilize debt by adopting both a nominal expenditures ceiling and a surplus target. By 1998 the budget had swung back to surplus and debt was on a downward trajectory.

\footnotetext{
${ }^{6}$ The Riksbank had plans to go as high as 4000 percent [Swedish Ministry of Finance (2001)].

${ }^{7}$ Sweden is known for having unusually strong automatic stabilizers [Floden (2009), Calmfors (2009)].
} 
Jonung (2009) lists macroeconomic policy reforms as critical factors in resolving crises in both the financial sector and the real economy. Swedish policies continue to be guided by the reforms that grew out of the crises.

2.2.2. New Zealand. After a decade of poor economic performance, in July 1984 New Zealand launched comprehensive economic reforms that transformed the country's economic landscape. Over the previous decade, government debt had increased sixfold, inflation rates were chronically in the double digits, and the unemployment rate had risen from 0.2 percent to 4.9 percent.

Reforms were broad and deep. They included privatization and deregulation of industries, financial and trade liberalization, reform of public finance, and deregulation of labor markets [Evans, Grimes, Wilkinson, and Teece (1996)]. In terms of macroeconomic policies, the critical changes were the decision to allow the Kiwi dollar to float on March 4, 1985, the passage of the Reserve Bank of New Zealand Act in December 1989, and the Fiscal Responsibility Act in 1994.

New Zealand led the way in reform of its monetary policy. ${ }^{8}$ Although at the time other central banks were operating with considerable autonomy - for example, the German Bundesbank, the Swiss National Bank, and the U.S. Federal Reserve - the Reserve Bank Act was the first to establish that the central bank's primary function was "achieving and maintaining stability in the general level of prices." The Act also required the Governor of the RBNZ and the Minister of Finance to negotiate a Policy Targets Agreement (PTA), which laid out specific targets - in practice, an inflation target - that the Bank would aim to hit. Transparency was served by publicly announcing the PTA. Accountability was addressed by making the Governor's contract conditional on achieving the agreed upon targets; in principle the Governor could be dismissed or not renewed for failing to attain the targets. The Reserve Bank Act and its implementation were bold initiatives that began the worldwide movement toward inflation targeting, the monetary policy regime now adopted by more than 20 central banks.

As in Sweden, fiscal reforms in New Zealand progressed more gradually. In the decade from the early 1980s, New Zealand sovereign debt was downgraded three times, from AAA to AA-. Estimates of default and liquidity premia on its debt ranged from about 125 basis points in 1990 to 75 basis points in 1994 [Hawkesby, Smith, and Tether (2000)] when the debt-GDP ratio had climbed to over 50 percent. Just as monetary policy became focused on a single objective - inflation targeting - fiscal reforms were designed "to provide stable policies rather than stabilization policies," as (Evans, Grimes, Wilkinson, and Teece, 1996, p. 1863) put it.

\footnotetext{
${ }^{8}$ Lloyd (1992) provides a nice overview.
} 
Fiscal reforms culminated in the Fiscal Responsibility Act of 1994, which shifted focus from short-run economic and political issues to strategic and long-run objectives [Scott (1995)]. Out of the Act grew enhanced transparency in the form of detailed accounts and long-run projections, which are made public. It also mandates that sovereign debt levels should be at "prudent levels," a mandate that is now interpreted as an informal debt target of 20 percent of GDP, a level that presumably will ensure that New Zealand sovereign debt is not assessed a substantial default premium.

2.3. Summary. Many countries, in addition to Sweden and New Zealand, transformed their monetary policies, adopting either explicit or de facto inflation targeting. Advocates of the monetary policy transformation point to data like those depicted in figures 2 and 3 as evidence that the monetary transformation has been highly successful. Both the average level and the volatility of inflation across countries have declined markedly over the past 20 years [figure 2]. And the success with inflation begat less variation in output growth in those same countries, a phenomenon that has been labeled, perhaps immoderately, "the great moderation" [figure 3].

Those advocates attribute these two striking successes entirely to monetary policy reforms that have delivered better policies. But for many countries whose data appear in those figures, the years from the mid-1980s to 2007 were particularly benign, with only mild recessions and no large and persistent adverse economic shocks. ${ }^{9}$

Benign, that is, until now. The current global recession and financial crisis are testing the view that monetary policy alone can deliver good economic performance.

\section{Parallels Between Monetary and Fiscal Policies}

Despite the willingness of economists to concede that fiscal policy may drive inflation in extreme circumstances, such as hyperinflations, those same economists hold fast to the view that "normally" monetary policy alone can control inflation, if only central bankers have sufficient resolve. I now develop the argument that in the realm of inflation control, as well as other matters, it is generically true that it is the joint behavior of monetary and fiscal policy that matters, even in normal times.

Classic writings about macroeconomic policies recognized the inherent symmetry between monetary and fiscal policies. For example, Friedman's sweeping policy prescriptions treated the two branches of macroeconomic policy equally [Friedman (1948, 1960)]. In later years, when Friedman began to discuss monetary policy exclusively, his critics shot back that fiscal policy and government liabilities, such as debt, needed

\footnotetext{
${ }^{9}$ In this same set of countries, New Zealand stands out as the exception, with the recession in the early 1990s producing large negative growth rates in GDP.
} 
to be brought in as equal partners with monetary policy and money [Brunner and Meltzer (1974, 1972), Tobin (1974, 1980), Tobin and Buiter (1976)].

The profound influence of Friedman's later work is apparent even today. Leading graduate textbooks in monetary economics by Walsh (2003), Woodford (2003), and Gali (2008) discuss monetary policy in tremendous detail with only scant, if any, reference to fiscal policy, and then only to acknowledge that the book's maintained assumptions serve to trivialize fiscal policy. Walsh (2003) does contain some discussion of fiscal theories of the price level, but treats them as a distinct perspectives on macro policy, rather than as an integral part of a comprehensive view of price level determination. The bulk of the book, however, examines monetary policy in isolation from fiscal policy. Discussions by leading monetary economists about monetary frameworks and inflation targeting rarely, if ever, mention fiscal policy [Bernanke and Mishkin (1997), Bernanke, Laubach, Mishkin, and Posen (1999), Rotemberg and Woodford (1999), Svensson (1999), Taylor (1999), Goodfriend (2005)]. Econometric models estimated at central banks typically treat fiscal policy in only the most perfunctory manner, if they include it at all [Brayton and Tinsley (1996), Smets and Wouters (2003, 2007), Harrison, Nikolov, Quinn, Ramsey, Scott, and Thomas (2005), Adolfson, Laseen, Linde, and Villani (2007)]. ${ }^{10}$

I will take the position that, despite the established tradition of treating monetary policy separately from fiscal policy, there are remarkable parallels between how monetary and fiscal policies operate on the macro economy and that these parallels are sufficient to lead us to think about transforming fiscal policy and fiscal institutions as many countries have transformed monetary policy and monetary institutions. Indeed, it makes little sense to reform monetary policy independently of fiscal policy.

Four important parallels stand out: macroeconomics impacts, the centrality of expectations for policy effects, ensuring government solvency, and the importance of transparency and credibility for policy effectiveness. In what follows, I focus on fiscal policy because much has already been written about these issues with regard to monetary policy.

3.1. Macroeconomic Impacts. Both monetary and fiscal policies can influence real economic activity and control inflation, and both do so with, in Friedman's (1961) famous phrase, "long and variable lags." That changes in tax distortions and government purchases can have important effects on the real economy is widely accepted. Empirical evidence suggests that for a variety of reasons, even changes in non-distorting taxes and transfers have real effects.

\footnotetext{
${ }^{10}$ The International Monetary Fund's "Global Integrated Monetary Fiscal Model" is an important exception [Kumhof and Laxton (2008a)].
} 
Fiscal policies play an important countercyclical role in many countries. Automatic stabilizers are built into tax codes and expenditure programs that ensure that during economic downturns tax burdens decline while government transfers increase, with the aim of cushioning individuals against declines in their incomes. In Sweden, for example, automatic stabilizers are large and have been relied on as nearly the sole source of countercyclical policies during the 2007-2009 recession [Floden (2009), Borg (2009)]. "Discretionary" policies, which require legislative action, are a form of countercyclical response that has played a major role in the current recession [examples of recent fiscal initiatives appear in Romer and Bernstein (2009), HM Treasury (2009a), Australian Treasury (2009), and New Zealand Treasury (2009)].

Less well appreciated, and less studied, are the impacts of fiscal policy on inflation. Recent research under the rubric of the "fiscal theory of the price level" argues that under certain assumptions about monetary and fiscal policy behavior, it is fiscal policy, rather than monetary policy, that determines the price level and the rate of inflation. ${ }^{11}$

At its most basic level, the fiscal theory brings to the foreground the role of an intertemporal equilibrium condition that in most monetary-only analyses of inflation is swept into deep background. This equilibrium condition, which equates the value of outstanding government liabilities - money plus bonds - to the expected present value of net-of-interest fiscal surpluses inclusive of seigniorage revenues, is ubiquitous in formal economic models and intrinsic to thinking about policy in dynamic economies. Schematically, the intertemporal equilibrium condition (IEC) is expressed as

$$
\begin{gathered}
\text { Market Value of Liabilities }= \\
\text { Expected Present Value of Future Net Surpluses }
\end{gathered}
$$

where

Net Surpluses $=$ Total Revenues + Central Bank Seigniorage

- Government Consumption \& Investment - Government Transfer Payments

Importantly, the expected present value of surpluses reflects the beliefs that holders of government liabilities have about the entire future paths of the policy variables that constitute net surpluses.

It is natural to interpret expression (IEC) as a valuation formula for liabilities [Cochrane (1999)]. Government liabilities derive their value from their anticipated backing. That backing comes from the government's ability to raises revenues through direct taxes or through inflation taxes, as well as the ability to reduce spending obligations.

\footnotetext{
${ }^{11}$ These papers include Leeper (1991), Sims (1994), Woodford (1995, 2001a), Cochrane (1999), Gordon and Leeper (2006), and Leeper and Yun (2006), among many others.
} 
Following an economic disturbance that perturbs the equality in the (IEC), equilibrium can be reestablished through some combination of adjustments in the value of the liabilities - prices of bonds or the general price level — or in expected surpluses. ${ }^{12}$ Stark forms of monetary or fiscal theories of price level determination are distinguished by assumptions about how equality of the (IEC) is achieved.

Monetary theories assume adjustment occurs primarily through surpluses, typically in some non-distorting way, such as via lump-sum taxes. In this manner, monetary policy is free to determine the price level - as it does in characterizations of inflation targeting central banks - and thereby the value of government liabilities. Fiscal policy is relegated to a supporting role, as it is required to adjust future surpluses sufficiently to ensure the (IEC) holds. This monetary-fiscal policy regime is variously referred to as "monetary dominance" [Sargent (1982)], "monetarist/Ricardian" [Aiyagari and Gertler (1985)], or "active monetary/passive fiscal policy" [Leeper (1991)]. Of course, fiscal policy's supporting role is essential for monetary policy to be able to control inflation. If fiscal policy is unwilling or unable to provide appropriate support, monetary policy will lose control of inflation, a point that has been forcefully made by Sims (2005) in the context of inflation targeting and by Cochrane (2009) in reference to current macro policies.

Fiscal theories posit that surpluses do not systematically adjust to establish the (IEC), so adjustment must occur through the market value of liabilities. Because liabilities are denominated in nominal, or dollar, terms, changes in the price level alter their real value: a higher price level reduces their value and requires less backing from future surpluses. Alternatively, when government bonds have long maturities, their prices can adjust, which change long-term interest rates and, therefore, expected inflation [Cochrane (2001)]. Now monetary policy plays the supporting role by allowing to occur the fluctuations in the inflation rate that are needed to stabilize debt. The policy regime underlying the fiscal perspective is called "fiscal dominance," "nonRicardian," or "passive monetary/active fiscal policy." 13 Symmetrically, if monetary policy fails to provide support, then fiscal policy cannot control the price level.

Two striking conclusions emerge from the fiscal theory: newly issued nominal government debt is inflationary and increases in nominal interest rates induced by monetary policy behavior raise rather than lower inflation. Sims (2008) nicely summarizes the mechanisms at work:

\footnotetext{
${ }^{12}$ Of course, the discount rate can also play a role in the adjustment process, as empirical work seems to suggest [Chung and Leeper (2007), Leeper, Plante, and Traum (2009)].

${ }^{13}$ There is evidence that macroeconomic policies in some countries have been consistent with the fiscal theory equilibrium [Cochrane (1999), Sims (2001, 2008), and Woodford (2001a)]. Davig and Leeper $(2006,2009)$ pursue the plausible idea that monetary and fiscal regimes fluctuate over time, bouncing among mixes of the two policies, according to estimates of policy behavior. In that environment, the fiscal mechanisms are always at work.
} 
"Increases in nominal debt in the hands of the public that are not accompanied by any increase in expected future tax liabilities or by any increase in the price level leave the public with apparently increased wealth, which they will try to spend, until price increases erode their wealth or expectations about future taxes or economic growth make them scale back spending. In these circumstances, an increased nominal interest rate flows directly through to increased nominal government spending. In a flexible price model, the monetary authority loses any ability to affect the price level, as interest rate increases increase the rate of expansion of nominal government debt without any restrictive effect on spending plans [p. 2]."

Two key roles of macroeconomic policies - output stabilization and price level control - can be achieved by either monetary or fiscal policy. Successful regimes that assign these tasks to either monetary or fiscal policy alone, however, require that the other policy cooperate by playing the appropriate supporting role.

3.2. Role of Expectations. A central tenet of modern economic analysis is that households and firms base their decisions, in part, on how they expect economic conditions to evolve in the future. Because future policies influence future economic conditions, economic agents must also form expectations over how policy choices will evolve. For monetary policy this forward-looking behavior implies that both the current policy interest rate and the expected path of interest rates indicate the stance of monetary policy that determines the impacts of policy. As Woodford (2001b) puts it: "... successful monetary policy is not so much a matter of effective control of overnight interest rates... as of affecting. . the evolution of market expectations...."

Transparency and clear communications are most important when people make forward-looking decisions. Most central banks now try to include in their communications with the public some information about the "tilt" or the "risks" to policy, revealing to some extent where the central bank thinks policy is headed. A handful of innovative central banks have taken communication about future policy to the next level. These banks, which include Canada, New Zealand, Norway, and Sweden, announce what they believe is the most likely path for the policy interest rate over the forecast horizon.

What's true about the role of expectations in transmitting the effects of monetary policy is true in spades about fiscal policy. There is substantial evidence that households and firms respond to tax changes at the time the changes are announced, which typically is before the changes are implemented [Poterba (1988, 1989), Steigerwald and Stuart (1997), Auerbach and Slemrod (1997), Ramey and Shapiro (1998), Ramey (2007)]. Moreover, economic theory is unambiguous in its predictions: anticipated 
changes in taxes or government spending can have large effects on economic behavior [Yang (2005), Mertens and Ravn (2008), Leeper, Walker, and Yang (2008, 2009a)].

Some kinds of taxes, such as those on savings, operate entirely through expectations. Consumption-savings decisions are influenced, not by the current tax rate on savings, but by the expected tax rate because it is the tax rate in the future that affects the expected return to saving. Firms' production and employment decisions depend on anticipated taxes on profits and payrolls. Government infrastructure spending, which takes time to reach fruition, gets transmitted to the macro economy through its impacts on expected productivity and anticipated returns to labor and capital [Leeper, Walker, and Yang (2009b)]. These are examples of how the direct effects of fiscal decisions can operate through expectations.

Expectations also play a key role in determining the indirect effects of fiscal actions. A quantitative sense of the potential importance of expectations in fiscal policy can be gleaned from estimates of fiscal effects in the United States taken from Leeper, Plante, and Traum (2009). These estimates come from a neo-classical growth model estimated on post-war U.S. data. The model includes rich fiscal detail, including policy rules for government spending, lump-sum transfers, and distortionary taxation on labor and capital income and on consumption expenditures. It also allows for debt dynamics, so spending increases or tax cuts are financed initially by selling government debt. Both the timing and the sources of fiscal adjustments that eventually retire debt back to its initial level are determined by historical experience.

Figure 4 reports conventional impact multipliers that report the dynamic effects of an initial $\$ 1$ increase in government spending on GDP. The top left panel is the best fitting model in Leeper, Plante, and Traum (2009) in which all fiscal instruments adjust to finance increases in government debt. In the short run output rises by about $\$ 0.65$, and then smoothly declines, with essentially no effect after about 5 years. The remaining panels of the figure report the effects under counterfactual assumptions about which future instruments will adjust to stabilize debt. When only lump-sum transfers are cut in the future (top right panel), the output multipliers are uniformly larger. If future government spending is cut (bottom left panel), the multiplier turns negative after about 2 years and reaches a trough at $-\$ 0.20$. But when future capital and labor taxes are expected to rise (bottom right panel), the multiplier becomes negative in a little more than a year and then falls to $-\$ 0.50$. This figure emphasizes that because dynamics play such a central role in transmitting fiscal policy, fiscal effects in the short run can differ dramatically from long run effects.

Differences among fiscal financing schemes emerge because forward-looking economic decision makers understand the nature of the fiscal rules in place and adjust their behavior accordingly. Although future fiscal financing considerations are indirect, they can be of first-order importance in projecting the impacts of, say, a fiscal 
stimulus engineered by increasing government spending. As the bottom two panels of the figure make clear, the stimulus may be short lived and even counterproductive if people believe that future government spending will be cut or future taxes will be raised.

With an estimated model of fiscal policy in hand, we can ask: "How long does it take for present-value balance to occur-that is, for the intertemporal equilibrium condition in (IEC) to be established - following fiscal disturbances that change the level of government debt outstanding?" The answer from U.S. data is: a very long time indeed; on the order of 25 to 35 years. Figure 5 answers the closely related question: "What fraction of a 1-unit change in government debt in quarter $t$, due to each of the five fiscal shocks, is financed by period $t+K$, where $K$ is determined by the quarters on the $x$-axis?" This is really about the discrepancy between the two sides of (IEC) when the left side changes by 1 unit and the right side is truncated $K$ periods into the future. Regardless of the fiscal shock, the discrepancy widens in the short run before the gap begins to close. The gap closes faster for some shocks than for others and in all cases, the gap is still substantial even 10 years after the initial change in fiscal policy. ${ }^{14}$

Figures 4 and 5 underscore three points about fiscal policy dynamics. First, fiscal effects depend strongly on expected future financing; even the signs of government spending multipliers can change under alternative financing schemes. Second, fiscal dynamics are long lived, extending many decades into the future. Third, fiscal impacts can change dramatically over time, so the total effect of a fiscal stimulus may be quite different from the initial effect. Each of these points connects explicitly to the role that expectations play in transmitting fiscal policy.

3.3. Ensuring Government Solvency. Either monetary or fiscal policy can ensure that the government is solvent, as touched on in section 3.1. Conventional wisdom has increases in government debt backed by some combination of higher future taxes and lower future government expenditures; these are the adjustments that occur in figures 4 and 5. "Passive" fiscal policy, which delivers this backing, is the most prevalent maintained assumption about fiscal behavior. ${ }^{15}$

But as the equilibrium condition (IEC) makes clear, other adjustments can occur to establish equilibrium. Here I mention three potential adjustments. First, Sargent

\footnotetext{
${ }^{14}$ Leeper, Plante, and Traum (2009) show through alternative counterfactual exercises that accelerating or decelerating fiscal adjustments - so the gap closes faster or slower - can have important consequences for the impacts of fiscal policy.

${ }^{15}$ Passive fiscal policy does not preclude periodic episodes in which fiscal instruments to not adjust to debt, so that debt grows rapidly for some time. But bond holders must believe that eventually the adjustments will occur. Davig (2005) applies this reasoning in his tests of the sustainability of U.S. fiscal policy.
} 
and Wallace (1981) study an environment in which government debt is indexed to inflation, there is a threshold level of government debt that the public is willing to hold, and taxes and expenditures are unresponsive to the state of government debt. Government rolls over debt until it reaches the threshold beyond which people are unwilling to absorb new debt issuances. At this point the only option available to ensure solvency is to print money to generate seigniorage revenues, as countries did during the hyperinflations discussed in section 2.1. This raises the seigniorage component of net surpluses on the right side of (IEC). Sargent and Wallace's point is that in such an environment the central bank loses control of inflation because the required inflation tax is driven by fiscal considerations.

A second set of adjustments that ensure solvency can arise when government issues nominal debt, rather than indexed, or real, debt. With outstanding nominal debt, the stage is set for the fiscal theory to operate, as section 3.1 describes. Debt can be revalued by changes in the price level that guarantee equality holds in expression (IEC). Once again, as the quotation from Sims (2008) in section 3.1 emphasizes, monetary policy loses control of the price level. Fiscal theory adjustments have no necessary connection to the seigniorage mechanism that Sargent and Wallace (1981) emphasize, although some authors have linked the two mechanisms [King (1995)]. Whereas seigniorage financing typically implies persistently higher money growth and inflation, the fiscal theory mechanism is more subtle and difficult to detect in data.

In all the potential adjustments just discussed - fiscal instruments, money creation, and price-level changes - the maintained assumption is that the government cannot default outright on its debt obligations. ${ }^{16}$ This assumption is at odds with how financial markets operate in practice, a fact into which treasuries and ministries of finance around the world are well tuned.

Fears of sovereign debt default in several countries have arisen during the recent global recession. In July 2009 Irish government debt was downgraded to AA and its risk premium over German bonds was nearly 3 percentage points. In May even the venerable United Kingdom had its sovereign bond rating placed on "negative watch" in response to forecasts that government debt as a share of GDP will reach 100 percent and remain there for the medium run.

More generally, countries are frequently penalized with risk premia when their macroeconomic fundamentals or their fiscal policies raise concerns about the riskiness of their government debt [Bi (2009)]. New Zealand government debt was downgraded from AAA to AA- over the period from 1983 to 1991 when net government debt grew to a peak of a bit over 50 percent of GDP. Because risk premia are costly, making debt

\footnotetext{
${ }^{16}$ But a type of default, surprise revaluations of debt, does occur under the fiscal theory.
} 
service consume a larger fraction of government expenditures, New Zealand adopted the fiscal reforms discussed above in section 2.2.2.

Even in the face of default risk and concerns about a country's fiscal soundness, the intertemporal equilibrium condition, (IEC), continues to hold. Risk premia serve to reduce the value of outstanding debt, reducing the left side of (IEC) to line up with expected future surpluses.

Taken literally, government "insolvency" means that a government's debt obligations exceed its ability to back the obligation: the left side of (IEC) exceeds the right side. But such an outcome is difficult to rationalize in an economy with well-informed and forward-looking investors because the (IEC) is a condition of economic equilibrium. So long as there is some positive price that investors are willing to pay for a government's debt, (IEC) must hold and the government is not insolvent.

Equilibrium condition (IEC) shifts the focus from "solvency" to the notion of "riskfree" policy. As Bi (2009) shows formally, risk-free policies ensure that in the face of shocks to economic fundamentals, the probability is negligible that an economy will reach its fiscal limit and investors will demand a risk premium to hold the government's bonds. ${ }^{17}$

Monetary and fiscal policy both play a role in delivering risk-free policies that keep government debt at a level where (IEC) can be satisfied without investors building in a risk penalty.

3.4. Most Effective When Transparent. Transparency of policy has been interpreted by fiscal authorities as referring to tracking how tax revenues get spent, achieving "value for money" from government programs, following accepted accounting standards, and conducting policy in an open and public way. These laudable goals have been codified by the International Monetary Fund [International Monetary Fund $(2007 \mathrm{a}, \mathrm{b})$. But these goals are really the minimal standards that a democratic society should expect from its government.

Central banks have pushed transparency to a higher plane. They take for granted that their decisions - both policy and non-policy - will be scrutinized by legislators, economists, and the public. This intense scrutiny has led the most transparent central

\footnotetext{
${ }^{17} \mathrm{Bi}$ (2009) distinguishes between the "natural fiscal limit" and the "maximum level of debt." A natural limit corresponds to the maximum tax revenues an economy can raise - the peak of the Laffer curves - when the (IEC) reflects the present value over the infinite future. Maximum level of debt is designed to reflect the populace's tolerance for government debt accumulation. It is derived by setting tax rates at the leak of the Laffer curve, but truncating the present value at some finite period to reflect a concern about policy only over the "foreseeable" future, rather than the infinite future. Bi interprets this lower debt threshold as the maximum level of debt an economy is able to service over some foreseeable horizon.
} 
banks to reveal to the public in written documents, public speeches, and news conferences three key aspects of their decision making processes: the objectives of monetary policy and the means by which the central bank tries to achieve the objectives; the central bank's views of the current state of the economy, including its understanding of the sources of shocks to the economy in the recent past; the central bank's forecasts of important economic variables, including at least some discussion of where future policy is likely to head. In sum, a transparent central bank communicates to the public whatever information it possesses that will help the public form its views about current and future states of the economy, which includes policy choices.

Using central banks as the model sets the transparency bar quite high for fiscal authorities. It also fundamentally redefines "transparency." To central banks, transparency is a means to the end of enhancing the effectiveness of monetary policy. By informing the public about the "hows" and the "whys" of monetary policy choices, efforts at transparency are designed to anchor the public's expectations of policy and of the targets of policy. In principle, transparency also reduces macroeconomic uncertainty by taking some of the guesswork out of policy intentions. Transparency, then, is a monetary policy tool that makes the central bank's other tools work better.

Fiscal transparency, as it is typically perceived, is less about the "hows" and "whys" of tax and spending decisions and more about establishing the integrity of and instilling trust in the fiscal policy process. With only a few minor exceptions, efforts at fiscal transparency do little to anchor expectations of future policy choices and, therefore, may not directly improve fiscal policy's efficacy.

Figure 4 illustrates that whether a government spending stimulus will successfully stimulate depends on how the public believes policy will adjust in the future to finance the higher spending. If the fiscal authority anticipates the new debt will be financed as debt has been historically (upper left panel), but the public believes future taxes will rise (lower right panel), the fiscal initiative could fail to stimulate the economy and could even cause output to contract sharply within a short time. When the public's expectations of fiscal financing are not aligned with the policy authority's, the impacts of fiscal actions become less predictable and, as the figure illustrates, can be counterproductive. This example highlights why it may be desirable for fiscal authorities to think about transparency as central banks do: anchoring expectations by providing information about what policies might occur in the future.

\section{Fiscal Transparency and Predictability}

For many reasons it is not an easy task to enhance fiscal transparency by providing information that helps to anchor expectations of future fiscal choices. The two most prominent reasons offered for the difficulties are: 
(1) Fiscal policy is complex;

(2) Current governments cannot commit future governments.

These reasons are true. But they also underscore why enhanced fiscal transparency is potentially so valuable.

4.1. Complexity. Whereas in normal times the central bank conducts routine monetary policy by setting one or two instruments - an overnight interest rate and possibly a rate at which commercial banks can borrow from the central bank - the fiscal authority routinely sets a seemingly endless array of instruments. ${ }^{18}$ There is a long list of tax rates on various sources of income and types of consumption and investment expenditures. Tax codes can be enormously complicated and imply highly non-linear tax functions. Government spending falls on a large variety of goods and services with different characteristics and potentially different impacts on the macro economy. Taxes and transfer payments affect income distribution and can have profound effects on economic incentives.

Fiscal decisions are taken by many actors with many motives. Political factions arise in response to some issues and dissolve in response to others. Lobbyists and groups representing small constituencies can have disproportionate influence on fiscal outcomes. Fiscal decisions, which are taken in the political realm, can be difficult for the public to understand, much less forecast.

Further complicating the fiscal decision process is a stunning fact: a clearly defined and attainable set of objectives for fiscal policy is rarely specified. Many fiscal authorities lay out their objectives on their web pages. Sustainable fiscal policy is the most common goal. But achieving sustainable policy is equivalent to aiming to avoid government insolvency. If a company's CEO were to announce to shareholders that the company's overarching goal is to avoid bankruptcy, the CEO would soon be replaced. Surely people can ask for more than minimal competence from their public officials.

Treasuries and ministries of finance, of course, do list objectives in addition to achieving sustainable policies. In fact, they tend to list many objectives to which they do not attach weights and whose internal compatibility is not discussed. Here is a sampling of objectives gleaned from the web pages of fiscal authorities in Australia, New Zealand, Sweden, the United Kingdom, and the United States: ${ }^{19}$ achieve

\footnotetext{
${ }^{18}$ In response to the current recession, central banks have pursued a number of non-standard policies, which have greatly expanded the effective number of instruments. But this has been a reaction to highly unusual circumstances, so presumably when times return to normal, central banks will go back to manipulating their usual instruments.

${ }^{19}$ Sources include Australian Treasury (2008), New Zealand Treasury (2003), Government Offices of Sweden (2009), HM Treasury (2009b), U.S. Department of the Treasury (2007).
} 
high and sustainable economic growth; improve living standards; promote a sound macroeconomic environment; reduce labor market exclusions; strengthen national security; encourage global economic growth; predict and prevent economic and financial crises; raise productivity; deliver conditions for business success; maximize employment opportunity; combat climate change; reduce poverty at home and abroad; equalize income distribution; support low inflation; build infrastructure; reduce smoking; minimize deadweight losses. The list could go on. In contrast, central banks in those same countries list their objectives as: maintain price stability; maintain full employment; ensure the safety and soundness of the financial system; promote moderate long-term interest rates; supply legal tender. This contrast highlights one reason that it is difficult for fiscal authorities to communicate about their future intentions: when fiscal objectives are diffuse and not prioritized, the public's expectations of fiscal actions will be equally diffuse and ill formed.

There is no disputing the complexity of fiscal policy. But complexity argues for more transparency, not less. The more ways that fiscal initiatives insinuate themselves into the public's decisions and the macro economy, the greater is the need for government to communicate with the public about the precise range of initiatives and their likely impacts. Fiscal complexity as an argument against enhanced transparency is a red herring.

4.2. Inability to Precommit. The second major stumbling block to improved fiscal transparency stems from the well known problem of the time inconsistency of government plans and has been invoked as a rationale for policymakers to follow rules, rather than apply discretion to their policymaking [Kydland and Prescott (1977)]. Mankiw (2006) clearly explains the problem:

"In some situations policymakers may want to announce in advance the policy they will follow to influence the expectations of private decisionmakers. But later, after the private decisionmakers have acted on the basis of their expectations, these policymakers may be tempted to renege on their announcement. Understanding that policymakers may be inconsistent over time, private decisionmakers are led to distrust policy announcements. In this situation, to make their announcements credible, policymakers may want to make a commitment to a fixed policy rule."

Time inconsistency applies to monetary policy, but it has been consciously attenuated by various institutional arrangements, such as a clearly stated objective like inflation targeting and other features that insulate central bankers from political pressures that might induce monetary policymakers to renege on their previously announced plans. 
Fiscal policy is rife with sources of time inconsistency. Fiscal actions that operate directly through expectations formation, by their nature, change future states of the economy, which can trigger future policy shifts. Elected governments are often short lived and have no mechanism to force future governments to follow through on earlier promises. $^{20}$ Short-lived governments can also be short sighted and pursue policies that leave fiscal messes, which future governments must clean up.

Some countries have made progress toward dealing with time inconsistency problems by adopting targets or rules for fiscal variables. Sweden imposes a nominal limit on government spending and it aims for a fiscal surplus of 1 percent of GDP. New Zealand has an informal net debt target of 20 percent of GDP. Members of the Euro Area are expected to obey the limits set by the Growth and Stability Pact - total annual deficits may not exceed 3 percent of GDP and debt may not exceed 60 percent of GDP. The United Kingdom follows a "Code for Fiscal Stability" that usefully distinguishes between current account and capital account expenditures and then applies the golden rule, which requires current account budgets to be balanced over the business cycle. Since the mid-1980s the United States has flirted with a variety of efforts to reign in fiscal deficits - ranging from Gramm-Rudman-Hollings to PAYGO. All of these measures were adopted more for reasons of sustainability than for transparency; they are ways of ensuring that fiscal policy does not get too out of whack.

To a limited degree, the rules may contribute to transparency. If government debt is currently above its target level - and the target is credible - then the public knows that in the future taxes must rise or spending must fall. This information helps expectations formation by eliminating some possible beliefs; for example, high debt will not be permitted to persist or to rise still more. Unfortunately, experience does not inspire confidence in the credibility of existing rules. When France and Germany violated the Growth and Stability Pact, the pact was watered down. Creative accounting or exemption of bills has allowed the U.S. Congress to circumvent every effort to impose fiscal discipline.

More generally, existing rules may be sufficient to deliver sustainability, but they are only necessary for achieving transparency. Rules that contribute importantly to transparency need to deal with the specifics of how sustainability is to be assuredwhich taxes and what spending will adjust and when will they adjust - and why the government is opting for the specified adjustments. Governments are far from providing this kind of information, which will help the public form reasonable expectations of future policies.

The argument that governments cannot precommit to future policies applies with equal force to the types of fiscal rules that countries have already adopted as it does to

\footnotetext{
${ }^{20}$ These issues arose in the debate that led to passage of New Zealand's Fiscal Responsibility Act in 1994 [Scott (1995)].
} 
the kinds of details that will help to guide the public's beliefs. Inability to precommit has also been raised by opponents to central bank moves to announce forward tracks for the policy interest rate. Experience in countries that announce tracks suggests that policy observers understand that the tracks are not commitments; they are state-contingent indications of where monetary policy is headed, which do not bind future decisions [Archer (2004)]. But the act of announcing a track imposes discipline on central bankers and forces them to think dynamically about their policy choices. Evidence also suggests that announced tracks help guide financial market expectations of interest rates.

Identical reasoning applies to fiscal policy. Regardless of how much information the fiscal authority supplies to the public, people are going to form expectations of future taxes and spending. Those expectations can be informed by the policymakers who choose fiscal variables or they can be diffuse, drawn solely from historical evidence or other source of information, such as talk radio. Fiscal authorities who fail to offer information that anchors expectations run the risk that figure 4 illustrates: fiscal initiatives can have unintended consequences.

\section{Transparency Going Forward}

Until the current global recession hit, many countries' fiscal positions were improving. Figure 6 shows that in Australia, New Zealand, and the United States the past two decades had seen steady declines in government debt as a share of GDP. New Zealand's net debt fell from a peak of over 50 percent in the early 1990s - when the debt was also downgraded by bond-rating agencies and interest rates on debt embedded a risk premium - to under 5 percent before the recession affected the country's public finances.

Declining indebtedness boded well for how these countries would enter a prolonged period in which their aging populations would impose growing demands on the government in the form of old-age pensions and health care. Some countries, like Australia and New Zealand but unlike the United States, have planned for these inevitable demands by creating superannuation funds [Janssen (2001), Gruen and Sayegh (2005)]. ${ }^{21}$ The current economic downturn may disturb those plans by placing countries in a worse fiscal state going forward. In the United States, for example, fiscal stimulus bills, financial rescues, and the Obama Administration's 2009-2010 budget are expected to double the debt-GDP ratio over the next decade, from 40 percent to 80 percent [Congressional Budget Office (2009a)].

\footnotetext{
${ }^{21}$ Norway's sovereign wealth fund is another well known example. Sweden's surplus target of 1 percent of GDP is designed, in part, to finance its aging population.
} 
Figures 7 through 9 show long-term projections of debt-GDP ratios for the United States, Australia, and New Zealand. ${ }^{22}$ Fiscal agencies produce such projections making assumptions about non-discretionary and discretionary spending, economic growth, inflation rates, immigration patterns, and so forth. Importantly, the projections do not embed assumptions that future surpluses will adjust to stabilize debt. They also rule out other potential adjustments, including various forms of reneging on future spending commitments. ${ }^{23}$ Evidently, fiscal issues will remain on the front burner for many years to come.

What can we learn from such projections? Two things. First, under the maintained assumptions, debt will grow exponentially in these countries. Second, the maintained assumptions - which produced the exploding debt paths - cannot possibly hold. We learn the second point from the intertemporal equilibrium condition. Figure 7 implies that within our children's lifetimes, U.S. debt will exceed the fiscal limit, violating the (IEC). ${ }^{24}$ These projections are public information and well understood by investors who continue to buy these government bonds without demanding a risk premium. Why do they continue to buy bonds? Because their expectations of future policy adjustments are at odds with the projections' maintained assumptions. In sum, figures of exploding debt paths, which fiscal authorities around the world routinely publish, arise from economic behavior that is not happening and which flies in the face of basic economic logic.

Having the future inherit larger government debt is problematic for several reasons. First, higher debt entails higher debt service and more government expenditures must be devoted to paying interest on outstanding debt. Historically, countries have found that higher debt service crowds out other forms of government expenditures. Second, as the intertemporal equilibrium condition, (IEC), implies, higher debt requires higher present-value surpluses. But that present value is bounded: as a share of GDP, tax revenues have some maximum level and spending has some minimum level. At those levels, the natural fiscal limit is reached and the economy cannot support a value of debt higher than that limit. By pushing more debt into the future, current policies move debt closer to the fiscal limit, which places restrictions on fiscal flexibility in

\footnotetext{
${ }^{22}$ Australian projections are from Australian Treasury (2007), so the short-run outlook does not reflect recent developments. The latest projections from the 2009-2010 budget now have net debt rising to about 14 percent of GDP by 2012 and remaining positive up to the end of the projection period, 2019 [Australian Treasury (2009)]. Similarly, New Zealand projections are from New Zealand Treasury (2006) and the 2009 budget forecasts that gross debt will be over 40 percent of GDP by 2014 [New Zealand Treasury (2009)].

${ }^{23}$ Reneging could be outright repudiation of the commitment or it could be more subtle. For example, eligibility ages for pensions could be increased or some benefits could be taxes.

${ }^{24}$ The U.S. fiscal limit is unknown, but I imagine it implies something less than a 300 percent debt-GDP ratio.
} 
the future. But the future is when the fiscal consequences of aging populations come home to roost; it is precisely when fiscal flexibility is most needed.

Additional reasons that higher debt is problematic tie back to transparency. Higher levels of interest payments require larger future fiscal adjustments. If the public is uncertain about the hows and whys of those adjustments, the macroeconomic consequences of the move to higher debt will be difficult to predict. But there is another more fundamental issue. In countries without guidelines governing debt levels, large debt run-ups leave unanswered a question that is critical to the public's formation of expectations: will the economy settle in at the new, higher level of debt or will policy endeavor to retire debt back to its previous level or some other level? The answer to this question is central to the public's ability to form reasonable fiscal expectations.

Many industrialized countries are heading into an extended period of heightened fiscal activity. Transparency will be more important than ever in the face of the inevitable public debates about how to handle the looming fiscal challenges.

\section{Steps Toward Fiscal Transparency}

To be clear, by fiscal "transparency" I mean having the government bring current and future fiscal decisions into the public debate. In this sense, transparency is really about anchoring fiscal expectations and raising the level of discourse about fiscal policy effects and financing options. Although for the reasons discussed in sections 4.1 and 4.2 it is difficult for fiscal policy to achieve a degree of transparency comparable to that in central banks, fiscal authorities could nonetheless strive to achieve it. This section lays out some steps that would enhance the transparency of fiscal policymaking institutions.

6.1. More Sophisticated Projections. Section 5 argues that the long-term projections in figures 7 through 9 cannot describe actual outcomes. Are such projections useful? Some would argue that they are because they make the point that in the absence of substantive changes in fiscal policies, policy is not sustainable. But this observation alone is of limited utility. First, we hardly need pictures showing that the debt-GDP ratio could reach 500 percent in 50 years to tell us that current policies cannot persist. Second, because the figures depict a scenario that cannot occur, they do nothing to help the public form expectations about how policies are likely to change. Third, the process that creates such projections is not sufficiently dynamic: "current policy" is an incomplete description of fiscal behavior because it ignores the fact that "future policy" can, and certainly will, be different.

Fiscal authorities could produce more sophisticated projections, grounded in economic reasoning, that characterize outcomes that, as a matter of economic logic, 
could occur. A minimal requirement is that the projections ensure that, among other things, equilibrium condition (IEC) is satisfied. Of course, there are many ways that the equilibrium condition can be made to hold. Transparent projections would then present a menu of the more interesting and relevant adjustments and show how other aspects of the macro economy are likely to evolve under each contemplated adjustment. For example, it would be interesting to report the consequences of the types of financing schemes underlying figure 4. This would force policy discussions to focus on the economic substance of fiscal issues. It could also serve to expose specious fiscal arguments that consist of political rhetoric and are devoid of economic support.

Figure 4, however, depicts a limited class of adjustments because the economic model behind the figure assumes that regardless of what happens to government debt in the short run, eventually it is retired back to its long-run average. Additional interesting scenarios would examine how outcomes would change if debt were to settle down at a permanently higher (or lower) level.

6.2. Independent Oversight. Some fiscal authorities, following their monetary brethren, have opened themselves to external scrutiny by establishing fiscal policy councils. Councils's remits vary from independent fiscal authorities (Belgium) to large government-run agencies that prepare assessments of fiscal proposals (the Netherlands, the United States) to independent "academic" agencies that evaluate whether the government's fiscal objectives are being achieved (Austria, Denmark, Sweden).

Kirsanova, Leith, and Wren-Lewis (2006) make an institutional proposal grounded in economic theory. They argue that optimal fiscal policy has debt, rather than tax rates, act as a shock absorber. To smooth tax distortions, debt follows a random walk, implying that debt targets produce sub-optimal outcomes. ${ }^{25}$ They find, though, that the optimal fiscal rules are sufficiently complex as to not be practically implementable. Instead of advocating those rules, Kirsanova, Leith, and Wren-Lewis propose that the United Kingdom establish a fiscal council that would produce annual long-term projections and assess sustainability and optimality of the government's plans. The council could also publish its preferred adjustments to policy. In Kirsanova, Leith, and Wren-Lewis's proposal, a fiscal council serves as a surrogate for a fiscal policy rule. Wyplosz $(2005,2008)$ takes this idea further to advocate the creation of independent fiscal policy committees with more bite. Modeled after central banks, Wyplosz's proposal gives the committees the task of achieving debt targets and the authority to set or recommend deficits.

${ }^{25}$ The random walk result is sensitive to how the possibility of debt default is handled. Pouzo (2009) shows that it breaks down in the presence of incomplete markets and endogenous default. See also Bi (2009). 
Even "soft" fiscal policy councils like those manned by academic economists can contribute to fiscal transparency by raising the right questions about policy. If current policies are unsustainable, which set of policies will set things right? What are the macroeconomic effects of various policies that stabilize debt? Why does the government favor one policy over another? Are the government's guidelines for sustainability appropriate or too harsh?

It is critical for the council to have a public forum. In Sweden, for example, the chair of the Swedish Fiscal Policy Council gives annual testimony before the Riksdag (the parliament) and the council's annual report is used by the Riksdag to evaluate the government's policies [Swedish Fiscal Policy Council $(2008,2009)$ ]. If councils offer independent and intellectually credible evaluations that receive public attention, the quality of public discussion of fiscal policy will rise well above its current levels.

6.3. Agree on Broad Principles. If fiscal authorities were given relatively narrow objectives, just as many legislatures have done for their monetary authorities, those objectives would need to be achievable and verifiable. This would require arriving at a political consensus on the goals of government spending and tax programs. To a large extent, fiscal decisions would then be a technical matter, just as many monetary policy decisions are now. ${ }^{26}$

I recognize that this is an exceedingly Panglossian perspective. Even small, largely homogeneous populations would have difficulty reaching consensus on the goals of fiscal policy. But perhaps it is possible for elected officials to reach agreement on some broad principles of fiscal policy. Without advocating them, I can offer some examples of such principles:

- reduce the complexity of current tax and spending rules;

- raise revenues in the least inefficient manner possible;

- use spending and transfer programs, rather than taxes, to achieve social goals, such as income redistribution;

- include (or not include) automatic stabilizers in fiscal policy rules;

- engage (or not engage) in discretionary countercyclical fiscal actions;

- manage government debt to avoid risk premia;

- aim to make fiscal policy as transparent as monetary policy;

- talk explicitly about current and future fiscal policy options and report likely economic outcomes of the options;

- produce long-term fiscal projections that make economic sense;

- adopt fiscal policy rules that are compatible with monetary policy rules;

${ }^{26}$ This is the aim of the "science of monetary policy," in Clarida, Gertler, and Gali's (1999) rather hopeful phrase. The practice of monetary policy remains - and probably always will be - more than a technical matter [Faust (2005)]. 
- ensure that fiscal principles do not conflict with monetary policy objectives.

This is intended to be a suggestive, rather than an exhaustive list of fiscal principles. Each society will have its own set of principles on which consensus can be reached.

A well-understood set of principles to guide fiscal decisionmaking provides a framework within which the technical analysis of how to design policies that satisfy the principles can progress.

6.4. Reach Consensus on Rules. Once a broad set of principles has been agreed on, fiscal authorities can develop rules for determining spending and taxation decisions that are consistent with the principles. As discussed, many countries have jumped to this step without first establishing the guiding principles. Rules that enforce sustainability have been adopted without checking whether those rules conflict with other aims of fiscal policy. There is no unique set of fiscal rules to ensure policy is sustainable. But almost certainly some rules for sustainability will prevent governments from pursuing other objectives such as countercyclical policy. Fiscal policy is intrinsically a general equilibrium problem and fiscal policy design must be approached from a general equilibrium perspective.

Academic research on fiscal policy is at a shockingly nascent stage. The dynamic consequences of various fiscal financing schemes have only begun to be explored. Optimal fiscal policy prescriptions tend to be so sharply at odds with observed policies that it is difficult to know how seriously the prescriptions should be taken. Econometric models of fiscal behavior remain crude and to date there are few micro-founded models that integrate monetary policy with sufficient fiscal detail to address practical questions. ${ }^{27}$ Recent global macroeconomic developments have made apparent the shortcomings of existing models, and work is already underway at several central banks to address those shortcomings.

Answers to fundamental questions about fiscal policy still lack professional consensus. There are examples in which countercyclical fiscal policies can be unhelpful or counterproductive [Eser, Leith, and Wren-Lewis (2009), figure 4, Gordon and Leeper (2005)], yet the modal view is that automatic stabilizers "quietly do their thing" [Cohen and Follette (2000), Domenech and Andres (2005), Schmitt-Grohe and Uribe (2007), Andres, Domenech, and Fatas (2009)]. Most economists contend that government debt crowds out private capital, but this conclusion depends on the underlying source of the debt expansion, the anticipated future adjustments that finance the debt, and assumptions about monetary policy behavior [Leeper and Yang (2008), Davig and Leeper (2009)].

\footnotetext{
${ }^{27}$ Though the International Monetary Fund has made progress along these lines with its global model [Kumhof and Laxton (2008a,b)].
} 
In contrast, hundreds of papers have been written about rules for monetary policy that deliver good economic outcomes and are robust to various forms of misspecification of the model. Analogous work in models that integrate monetary and fiscal policy can begin to discover implementable rules for fiscal policy that produce outcomes consistent with the fiscal principles. Optimal fiscal rules are extraordinarily complex and highly model dependent. Are there robust "simple" rules that can come close to replicating the outcomes of the optimal ones? Relatively simple fiscal rules can then be used as benchmarks to be compared to actual policy behavior, much as Taylor's (1993) rule is used in monetary policy analysis.

Naturally, as with monetary policy, fiscal authorities should consider rules that are explicit about the state-contingent nature of their decisions. Under what conditions can the public expect taxes to increase? When will discretionary countercyclical actions take place? What elements will be included in a countercyclical package? During periods of debt run-ups, how rapidly can people expect policies to adjust to stabilize debt?

Inevitably, fiscal rules will be more complex than monetary rules. Fiscal rules will need to apply to a large set of instruments and handle a variety of contingencies. And, of course, fiscal decisions ultimately are made in the political arena, rather than by one or a small handful of technocrats. But if society can agree on fiscal principles and fiscal authorities can derive rules consistent with those principles, huge strides toward transparency and anchoring expectations will have been taken.

6.5. Establishing Credibility. To this point I have used the term "fiscal authority" without distinguishing between the treasury or ministry of finance and the elected officials who propose and vote for spending and tax legislation. All the transparency in the world will do little to anchor fiscal expectations if the actual fiscal decisionmakers' communications about fiscal plans are not credible.

How can elected officials establish credibility? The standard answer is for them to do as they say and say as they do. True enough. But how can such behavior be institutionalized to instill it across elected officials and across time?

Here it is useful to point out an important difference between monetary and fiscal decisionmakers. Central bankers can be held accountable and earn credibility because they own their decisions and the economic analyses and projections underlying those decisions. Central banks around the world employ sizeable staffs of professional economists who produce high-quality research that finds its way into board rooms, central bank communications with the public, and leading academic journals. Many 
central banks publish the econometric models they use in their routine policy analysis. $^{28}$ Some banks even include in their public reports explicit references to results from their models [for example, Sveriges Riksbank (2007)]. By devoting substantial resources to the analyses behind their policy choices and then exposing the analyses to the public, monetary policymakers consciously take ownership both of their decisions and their economic rationales. Recognizing that there may also be grounds for dissenting views well grounded in economic reasoning, some central banks also publish the minutes of their meetings [for example, Sveriges Riksbank (2009)].

Nothing comparable occurs with fiscal policy. Fiscal decisionmakers do own their votes and they can be held accountable for those votes at election time. But fiscal decisions are only a small subset of the votes that legislators place, so fiscal votes can easily get lost in the morass of electoral politics. More importantly, even if legislators own their fiscal decisions, they rarely own the economic analysis underlying the decisions. In fact, as an institutional matter, legislators tend consciously to distance themselves from the nitty gritty economic details. Instead, fiscal decisionmakers farm out the analysis and forecasting to autonomous or semi-autonomous agencies, which ensures that decisionmakers do not have to ascribe to any particular analysis or set of projections.

Legislators could adopt procedures similar to those as central banks. Political coalitions could employ economists whose models and forecasts would be public and subjected to independent professional scrutiny. Each legislator's vote and underlying economic rationale would be recorded and made public. Because coherent economic analyses would be dynamic and satisfy the intertemporal equilibrium condition, they would necessarily embed assumptions about both current and future policies. By owning a fiscal projection, decisionmakers would also be revealing their views about likely and desirable future policy adjustments. Future decisionmakers, of course, would not be bound by these views. But the act of revealing the views also brings them into sharp focus and into the public discourse about fiscal options. In this way, the discourse about fiscal decisions can also help to guide the public's expectations about future policies.

\section{Concluding Remarks}

I shall end with an egregious example of non-transparent fiscal policy: the recent $\$ 787$ billion American fiscal stimulus plan. Leading up to the introduction and passage of the American Recovery and Reinvestment Act, the entire economic rationale for the

\footnotetext{
${ }^{28}$ Examples include Poloz, Rose, and Tetlow (1994), Brayton and Tinsley (1996), Smets and Wouters (2003), Reserve Bank of New Zealand (2004), Harrison, Nikolov, Quinn, Ramsey, Scott, and Thomas (2005), Adolfson, Laseen, Linde, and Villani (2007).
} 
stimulus package consisted of the job creation prediction in a document by Romer and Bernstein (2009). ${ }^{29}$ An appendix to the document reports multipliers for a permanent increase in government spending and decrease in taxes of 1 percent of GDP. Four years after the initial stimulus, government purchases raise GDP by 1.55 percent, while tax cuts raise GDP by 0.98 percent. Sources for these numbers are reported as the Federal Reserve's FRB/US model and "a leading private forecast firm."

To assess how this rationale for stimulus measures up in terms of transparency, I raise some questions that are not addressed in the Romer-Bernstein document, but are important for anchoring fiscal expectations:

- What are the economic models underlying the multiplier numbers and are those numbers reproducible?

- Why consider permanent changes in fiscal variables when the Act makes transitory changes?

- What are the consequences of the stimulus for government debt?

- What are the repercussions of significantly higher government debt?

- Will the debt run-up be sustained or retired?

- How will policies adjust in the future to either sustain or retire the debt?

Some might accuse me of finding a straw man to ridicule. But this is an important example because of its potential impact on the world economy. At over 5 percent of U.S. GDP, this is the world's largest stimulus in response to the current recession [International Monetary Fund (2009)], and that figure does not include the 2008 tax rebate or the substantial financial rescue packages.

Some might also argue that the United States is a bad example because it has among the least transparent fiscal policies. I grant that. But measured against the bulleted items above, few fiscal authorities would emerge looking very transparent.

Principles, guidelines, rules, and independent oversight may help to improve the transparency and efficacy of fiscal policy by nailing down the private sector's expectations. Or they can provide a smoke screen behind which fiscal shenanigans can proceed as usual.

To be successful, fiscal principles need to reduce the complexity of fiscal policy. This can be accomplished at the implementation stage when the principles are transformed into quantifiable rules governing fiscal decisions. It may be necessary to provide statutory or even constitutional protections for the rules. Rules that are adopted in a frenzy are likely to be ill-conceived and can easily have deleterious effects.

\footnotetext{
${ }^{29}$ A follow-up report in May 2009 contains further predictions [Council of Economic Advisors (2009)].
} 
Research has not yet quantified the social costs of the uncertainty about fiscal policy that non-transparent policies engender. Neither has research explored the possible consequences of unanchored fiscal expectations. Both of these issues need to be understood.

But some things are certain. Fiscal policy is too important to be left to the vagaries of the political process. Reform of fiscal institutions, the design of fiscal rules, and fiscal decisions can be informed and guided to a much larger extent by careful economic analysis. Failure to achieve appropriate fiscal reforms threatens to undermine the progress made on monetary policy and, in the face of the looming heightened fiscal activity, the stability of macro economies. 


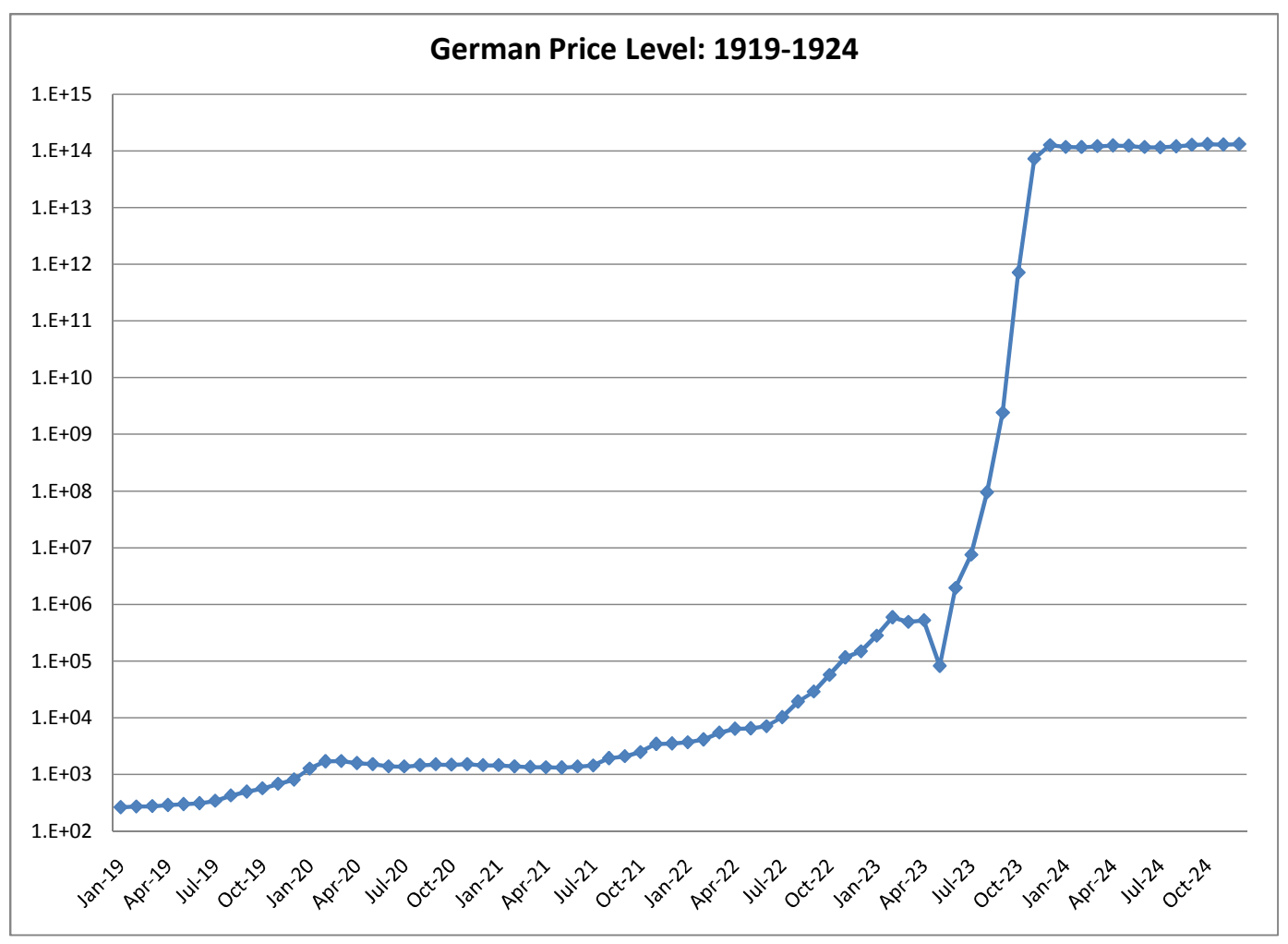

Figure 1. The price level in Germany during the interwar era. Vertical scale is logarithmic. Source: Sargent (1986). 


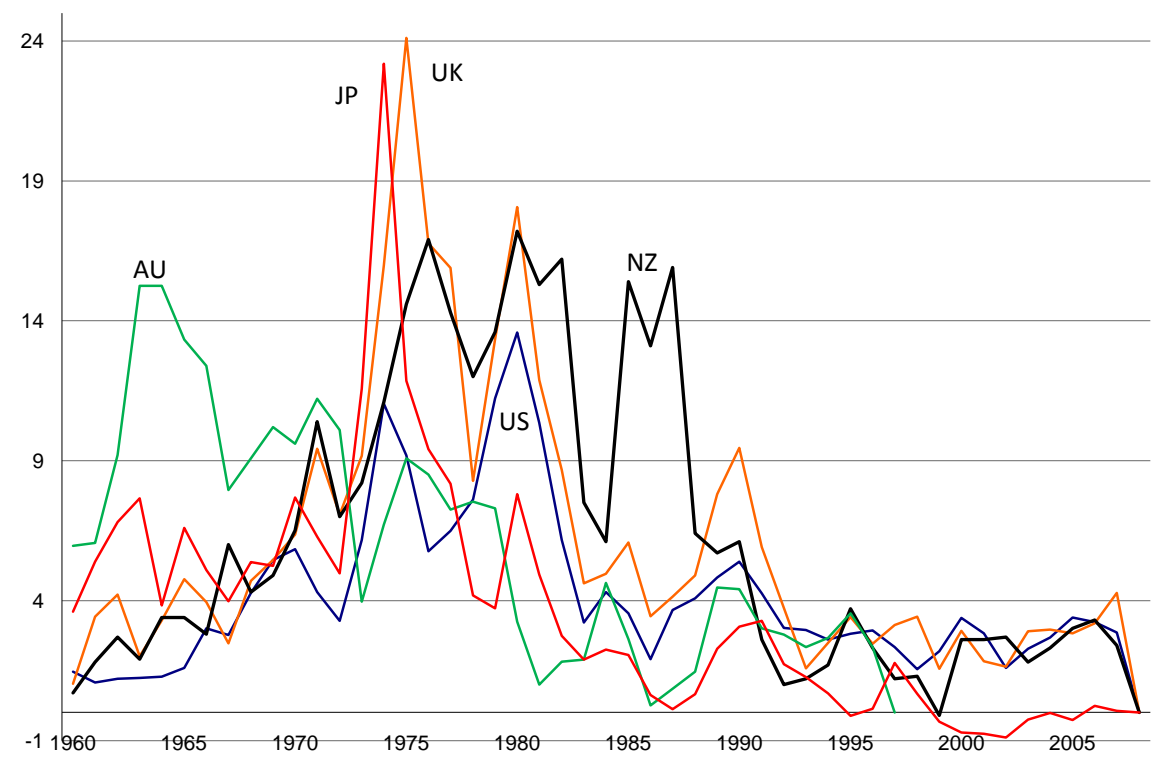

FiguRE 2. Inflation rates in selected countries. Vertical scale is annual percentage points. Source: OECD Economic Outlook, various issues, and Reserve Bank of New Zealand. 


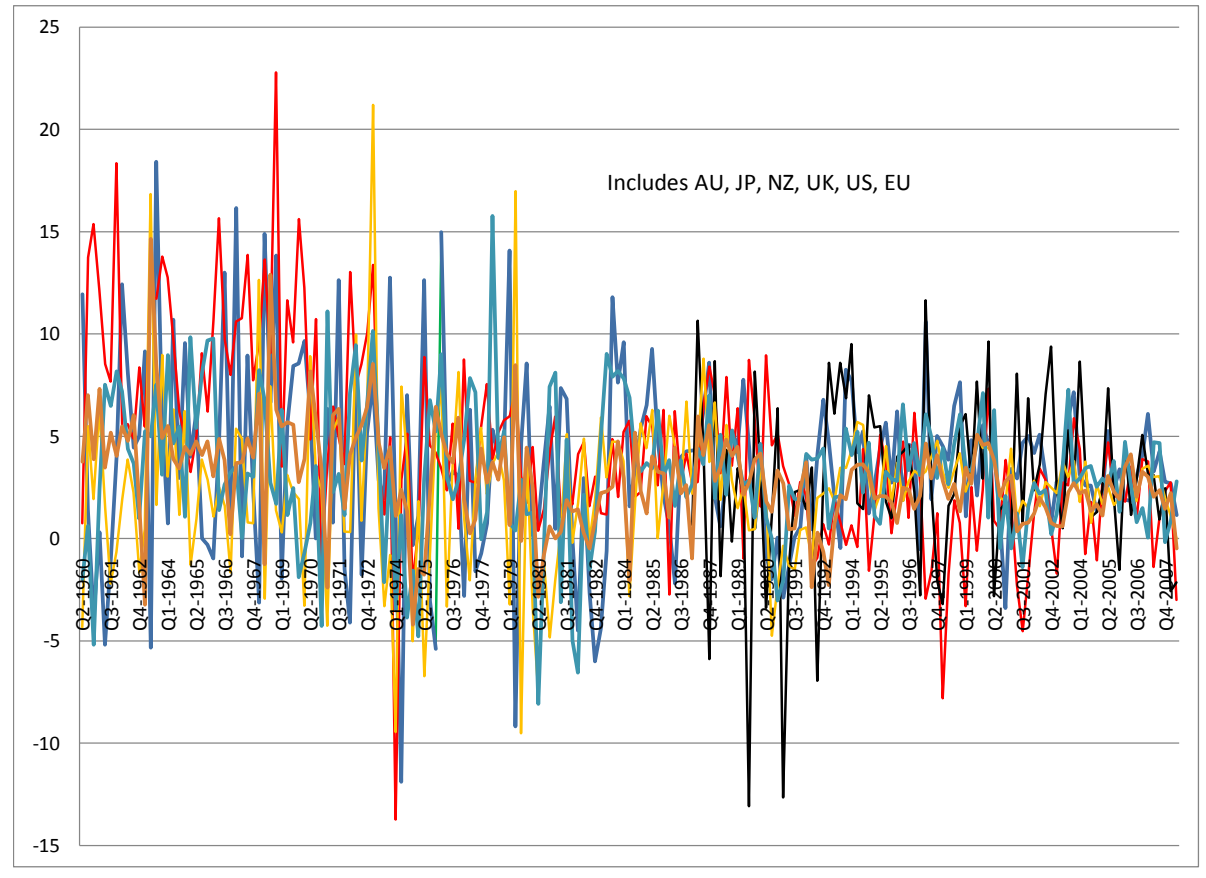

FiguRE 3. Output growth rates in selected countries. Vertical scale is annual percentage points. Source: OECD Economic Outlook, various issues, and Reserve Bank of New Zealand. 
All Instruments Adjust

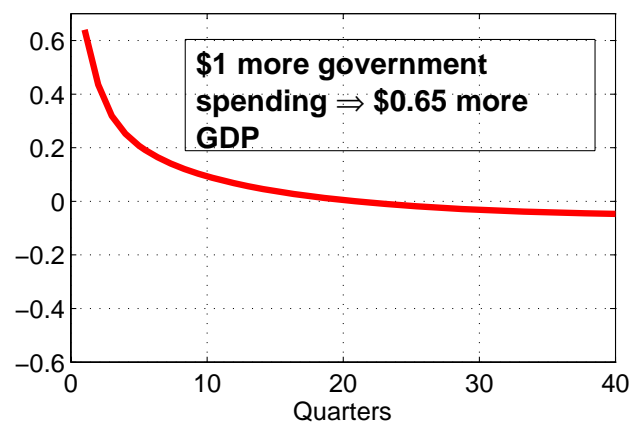

Only Government Spending Adjusts

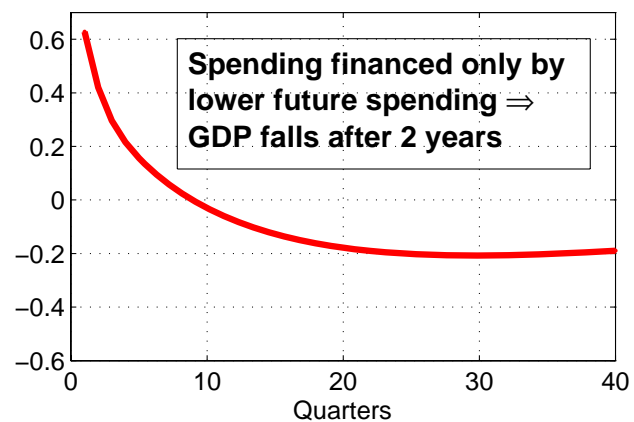

Only Transfers Adjust

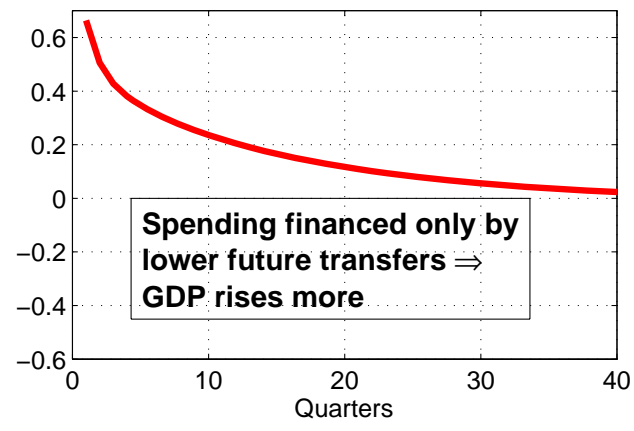

Only Taxes Adjust

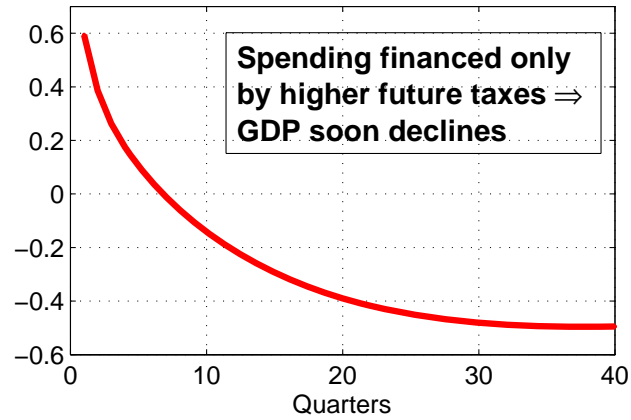

FIGURE 4. Government spending impact multipliers for output under alternative assumptions about fiscal financing. Top left panel is the best fitting model in Leeper, Plante, and Traum (2009) in which all fiscal instruments adjust to finance increase in government debt; top right panel only lump-sum transfers adjust; bottom left panel only government spending adjusts; bottom right panel only capital and labor taxes adjust. Vertical scale is dollars of output following an initial increase in government spending of $\$ 1$. Source: Leeper, Plante, and Traum (2009). 


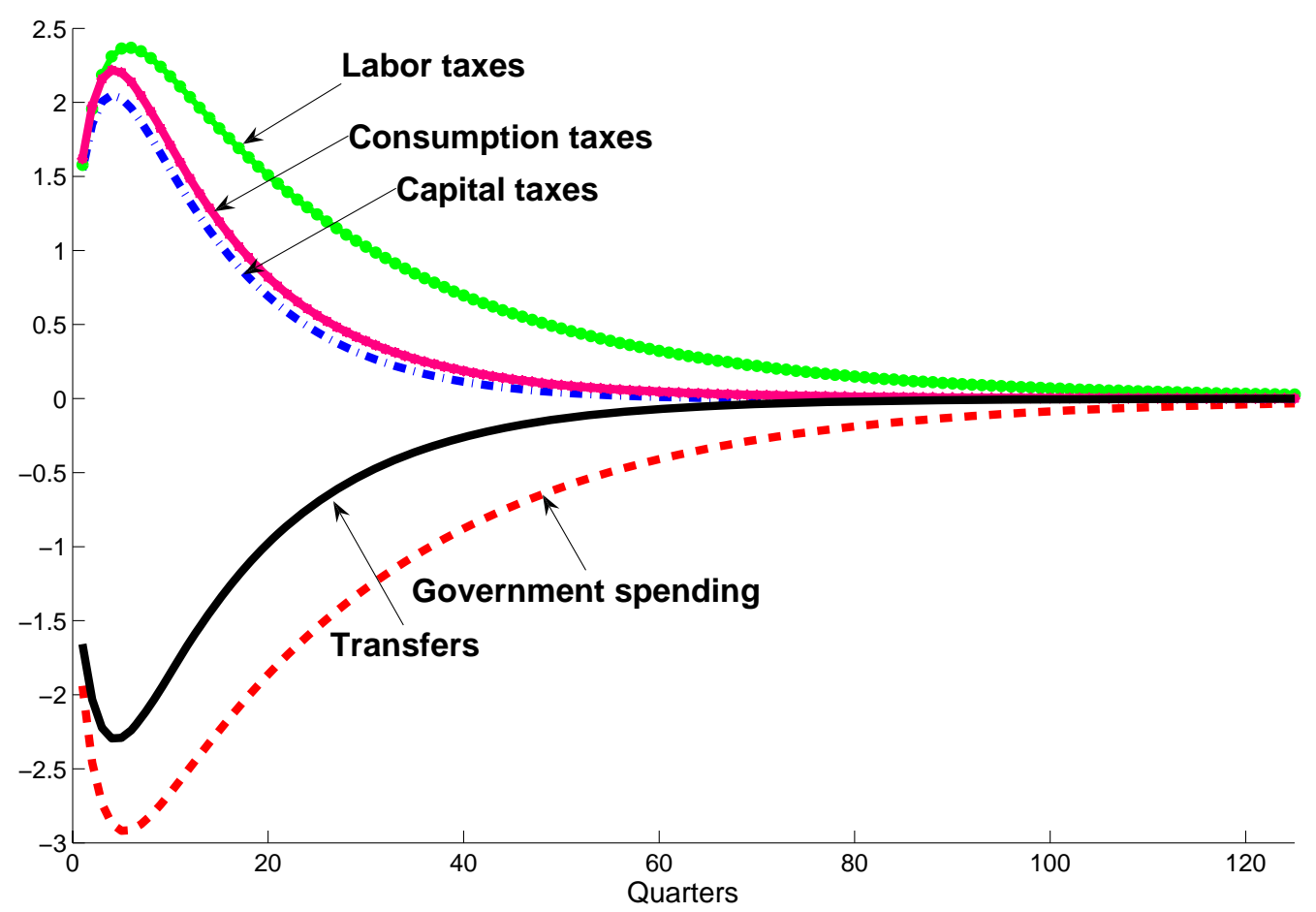

FiguRE 5. Government debt funding horizons for each of five fiscal shocks-labor taxes, consumption taxes, capital taxes, transfer payments, government spending - using the mean estimates of posterior draws from the model best fitting model in Leeper, Plante, and Traum (2009) where all fiscal instruments adjust to debt. The figure can answer the question, "What fraction on a 1-unit innovation in government debt in quarter $t$, due to each of the five fiscal shocks, is financed by period $t+K$, where $K$ is determined by the quarters on the $x$-axis?" The $\mathrm{x}$-axis units are quarters. Source: Leeper, Plante, and Traum (2009). 


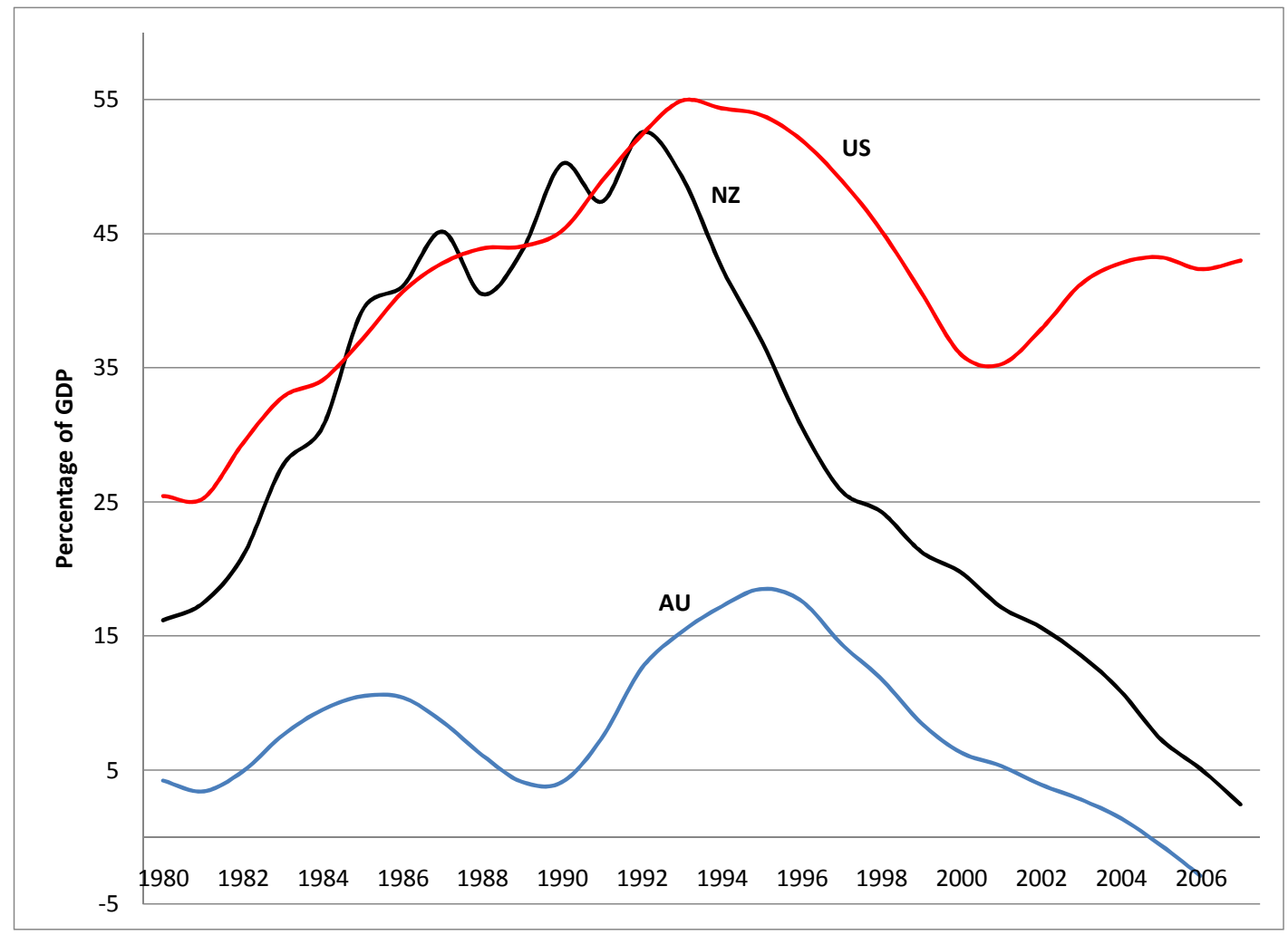

FiguRE 6. Net government debt as a percentage of GDP in Australia, New Zealand, and the United States. Source: OECD Economic Outlook, various issues. 


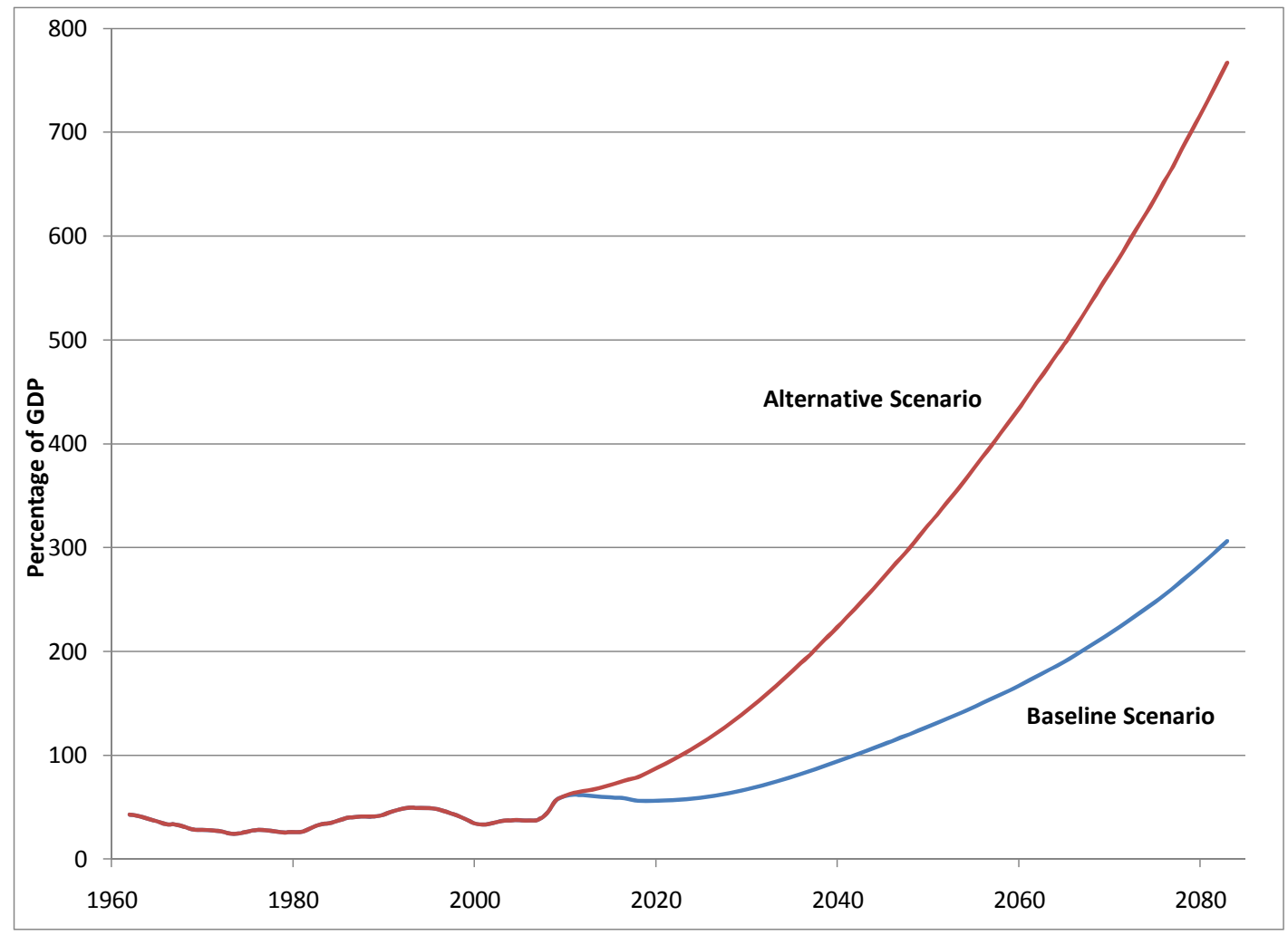

FigURE 7. Long-term projection of government debt as a percentage of GDP in the United States. Baseline scenario assumes current law remains in place; alternative scenario incorporates some policy changes that are widely expected to occur. Source: Congressional Budget Office (2009b). 


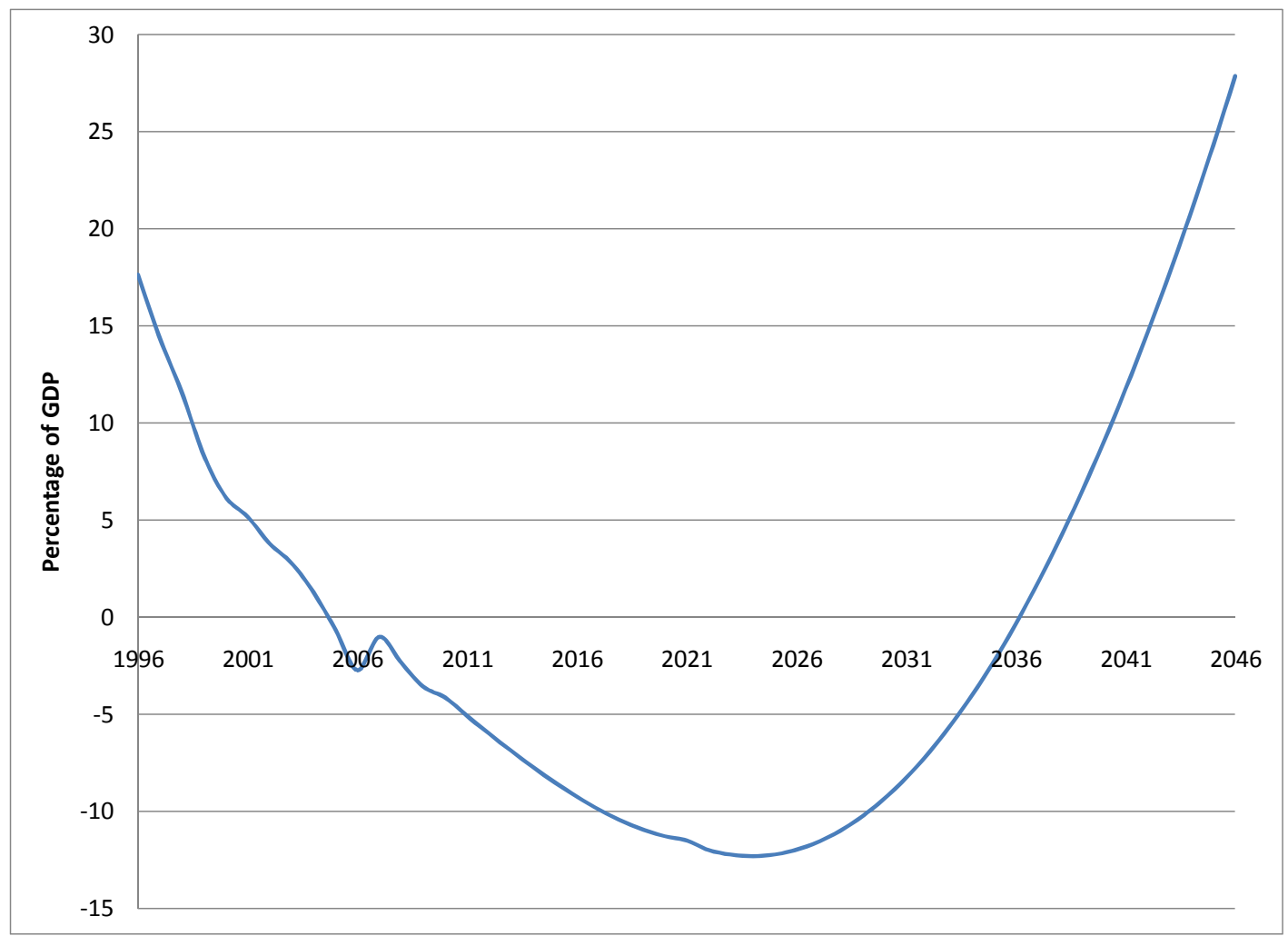

FiguRE 8. Long-term projection of net government debt as a percentage of GDP in Australia. Source: Australian Treasury (2007). 


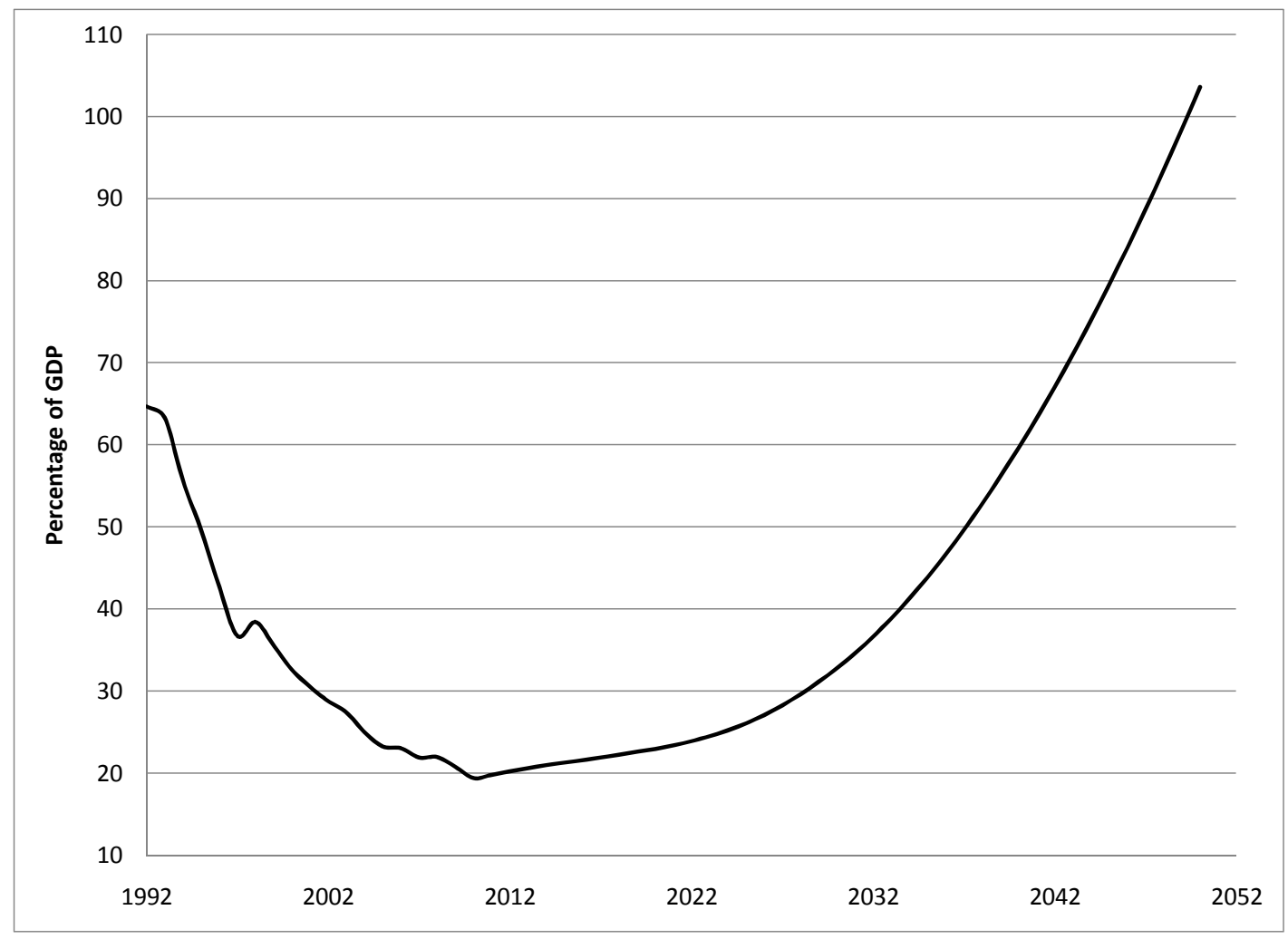

FiguRE 9. Long-term projection of gross sovereign-issued debt as a percentage of GDP in New Zealand. Source: New Zealand Treasury (2006). 


\section{REFERENCES}

Adolfson, M., S. Laseen, J. Linde, and M. Villani (2007): "RAMSES-A New General Equilibrium Model for Monetary Policy Analysis," Sveriges Riksbank Economic Review, 2, 5-39.

Aiyagari, S. R., And M. Gertler (1985): "The Backing of Government Debt and Monetarism," Journal of Monetary Economics, 16(1), 19-44.

Andres, J., R. Domenech, and A. Fatas (2009): "The Stabilizing Role of Government Size," Journal of Economic Dynamics and Control, 32(2), 571-593.

Archer, D. (2004): "Communication with the Public," Manuscript, Reserve Bank of New Zealand.

Auerbach, A. J., And J. Slemrod (1997): "The Economic Effects of the Tax Reform Act of 1986," Journal of Economic Literature, 35(2), 589-632.

Australian Treasury (2007): Intergenerational Report 200\%. Australian Government, Sydney.

- (2008): The Treasury: Who We Are and What We Do. Australian Government, Sydney.

May 12.

Bernanke, B. S., T. Laubach, F. S. Mishkin, and A. S. Posen (1999): Inflation Targeting: Lessons from the International Experience. Princeton University Press, Princeton, NJ.

Bernanke, B. S., and F. S. Mishkin (1997): "Inflation Targeting: A New Framework for Monetary Policy," Journal of Economic Perspectives, 11(2), 97-116.

Bı, H. (2009): "Sovereign Risk Premia and Fiscal Limits," Manuscript, Indiana University.

Blinder, A. S., M. Ehrmann, M. Fratzscher, J. De HaAn, and D.-J. Jansen (2008): "Central Bank Communication and Monetary Policy: A Survey of Theory and Evidence," Journal of Economic Literature, 46(4), 910-945.

Borg, A. (2009): "Swedish Perspective on the Crisis," Presentation, Ministry of Finance Sweden, April 24.

Brayton, F., and P. Tinsley (1996): "A Guide to FRB/US: A Macroeconomic Model of the United States," FEDS Paper No. 1996-42.

Brunner, K., And A. H. Meltzer (1972): "Money, Debt, and Economic Activity," Journal of Political Economy, 80(5), 951-977.

- (1974): "Friedman's Monetary Theory," in Milton Friedman's Monetary Framework, ed. by R. J. Gordon, pp. 63-76. University of Chicago Press, Chicago.

Calmfors, L. (2009): "Swedish Fiscal Policy: Meeting with IMF Country Mission," Presentation Slides, June 8.

Chung, H., and E. M. Leeper (2007): "What Has Financed Government Debt?," NBER Working Paper No. 13425. 
Clarida, R., J. Gali, and M. Gertler (1999): "The Science of Monetary Policy: A New Keynesian Perspective," Journal of Economic Literature, 37(4), 1661-1707. Cochrane, J. H. (1999): "A Frictionless View of U.S. Inflation," in NBER Macroeconomics Annual 1998, ed. by B. S. Bernanke, and J. J. Rotemberg, pp. 323-384. MIT Press, Cambridge, MA.

(2001): "Long Term Debt and Optimal Policy in the Fiscal Theory of the Price Level," Econometrica, 69(1), 69-116.

(2009): "Understanding Fiscal and Monetary Policy in 2008-2009," Manuscript, University of Chicago.

Cohen, D., And G. Follette (2000): "The Automatic Fiscal Stabilizers: Quietly Doing Their Thing," Federal Reserve Bank of New York Policy Review, 6, 35-68.

Congressional Budget Office (2009a): An Analysis of the President's Budgetary Proposals for Fiscal Year 2010, vol. June. CBO, Washington, D.C. D.C.

Council of Economic Advisors (2009): "Estimates of Job Creation from the American Recovery and Reinvestment Act of 2009," Executive Office of the President, Washington, D.C., May, http://www.whitehouse.gov/administration/eop/cea/Estimate-of-Job-Creation/.

Davig, T. (2005): "Periodically Expanding Discounted Debt: A Threat to Fiscal Policy Sustainability?," Journal of Applied Econometrics, 20(7), 829-840.

Davig, T., And E. M. Leeper (2006): "Fluctuating Macro Policies and the Fiscal Theory," in NBER Macroeconomics Annual 2006, ed. by D. Acemoglu, K. Rogoff, and M. Woodford, pp. 247-298. MIT Press, Cambridge.

- (2009): "Monetary-Fiscal Policy Interactions and Fiscal Stimulus," NBER Working Paper No. 15133.

Domenech, R., And J. Andres (2005): "Fiscal Rules and Macroeconomic Stability," Manuscript, University of Valencia.

Eser, F., C. Leith, and S. Wren-Lewis (2009): "When is Monetary Policy All We Need?," University of Oxford Discussion Paper No. 430.

Evans, L., A. Grimes, B. Wilkinson, and D. Teece (1996): "Economic Reform in New Zealand 1985-95: The Pursuit of Efficiency," Journal of Economic Literature, 34(4), 1856-1902.

FAust, J. (2005): "Is Applied Monetary Policy Analysis Hard?," Manuscript, Federal Reserve Board.

Faust, J., and D. W. Henderson (2004): "Is Inflation Targeting Best-Practice Monetary Policy?," Federal Reserve Bank of St. Louis Economic Review, 86(4), 117-143.

Faust, J., And E. M. Leeper (2005): "Forecasts and Inflation Reports: An Evaluation," Manuscript, Indiana University. 
Floden, M. (2009): "Automatic Fiscal Stabilizers in Sweden 1998-2009," SSE/EFI Working Paper Series in Economics and Finance No. 719.

Friedman, M. (1948): "A Monetary and Fiscal Framework for Economic Stability," American Economic Review, 38(2), 245-264.

York. (1960): A Program for Monetary Stability. Fordham University Press, New

(1961): "The Lag in the Effect of Monetary Policy," Journal of Political Economy, 69(5), 447-460.

Gali, J. (2008): Monetary Policy, Inflation, and the Business Cycle. Princeton University Press, Princeton.

Goodfriend, M. (2005): "Inflation Targeting for the United States?," in The Inflation-Targeting Debate, ed. by B. S. Bernanke, and M. Woodford, pp. 311-337. University of Chicago Press, Chicago.

Gordon, D. B., And E. M. Leeper (2005): "Are Countercyclical Fiscal Policies Counterproductive?," NBER Working Paper No. 11869.

(2006): "The Price Level, The Quantity Theory of Money, and the Fiscal Theory of the Price Level," Scottish Journal of Political Economy, 53(1), 4-27.

Government Offices of Sweden (2009): Budget Statement and Summary from the Budget Bill for 2009. Government Office of Sweden, Stockholm.

Gruen, D., And A. Sayegh (2005): "The Evolution of Fiscal Policy in Australia," Oxford Review of Economic Policy, 21(4), 618-635.

Harrison, R., K. Nikolov, M. Quinn, G. Ramsey, A. Scott, And R. Thomas (2005): The Bank of England Quarterly Model. The Bank of England, London.

Hawkesby, C., C. Smith, and C. Tether (2000): "New Zealand's Currency Risk Premium," Reserve Bank of New Zealand Bulletin, 63(3), 30-44.

HM Treasury (2009a): Budget 2009 Building Britain's Future: Economic and Fiscal Strategy Report and Financial Statement and Budget Report. The Stationery Office, London, April.

- (2009b): HM Treasury Group Departmental Strategic Objectives: 2008-2011. HM Treasury, London.

International Monetary Fund (2007a): "Code of Good Practices and Fiscal Transparency," http://www.imf.org/external/np/fad/trans/code.htm.

(2007b): Manual on Fiscal Transparency. International Monetary Fund, Washington, D. C.

- (2009): "The Size of the Fiscal Expansion: An Analysis for the Largest Countries," Mimeo, International Monetary Fund, February, http://www.imf.org/external/np/pp/eng/2009/020109.pdf.

Janssen, J. (2001): "New Zealand's Fiscal Policy Framework: Experience and Evolution," New Zealand Treasury Working Paper No. 01/25. 
Jonung, L. (2009): "The Swedish Model for Resolving the Banking Crisis of 199193: Seven Reasons Why It Was Successful," European Economy, Economic Papers 360, European Commission, Brussels.

King, M. (1995): "Commentary: Monetary Policy Implications of Greater Fiscal Discipline," in Budget Deficits and Debt: Issues and Options, pp. 171-183. Federal Reserve Bank of Kansas City, Jackson Hole Symposium.

Kirsanova, T., C. Leith, and S. Wren-Lewis (2006): "Optimal Debt Policy, and an Institutional Proposal to Help in its Implementation," Manuscript, Oxford University.

Kumhof, M., And D. Laxton (2008a): "The Global Integrated Monetary and Fiscal Model," Manuscript, International Monetary Fund.

(2008b): "Implementable Fiscal Policy Rules for Open Economies," Manuscript, International Monetary Fund.

Kydland, F., and E. C. Prescott (1977): "Rules Rather Than Discretion: The Inconsistency of Optimal Plans," Journal of Political Economy, 85, 473-492.

Leeper, E. M. (1991): 'Equilibria Under 'Active' and 'Passive' Monetary and Fiscal Policies," Journal of Monetary Economics, 27(1), 129-147.

Leeper, E. M., M. Plante, and N. Traum (2009): "Dynamics of Fiscal Financing in the United States," NBER Working Paper No. 15160.

Leeper, E. M., T. B. Walker, and S.-C. S. YAng (2008): "Fiscal Foresight: Analytics and Econometrics," NBER Working Paper No. 14028.

No. 14630.

(2009b): "Government Investment and Fiscal Stimulus in the Short and Long Runs," NBER Working Paper No. 15153.

Leeper, E. M., And S.-C. S. YAng (2008): "Dynamic Scoring: Alternative Financing Schemes," Journal of Public Economics, 92(1-2), 159-182.

Leeper, E. M., And T. Yun (2006): "The Fiscal Theory of the Price Level: Background and Beyond," International Tax and Public Finance, 13(4), 373-409.

Lloyd, M. (1992): "The New Zealand Approach to Central Bank Autonomy," Reserve Bank of New Zealand Bulletin, 55(3), 203-220.

Mankiw, N. G. (2006): "Time Inconsistency," Greg Mankiw's Blog, http://gregmankiw.blogspot.com/2006/04/time-inconsistency.html, April 19.

Mertens, K., And M. Ravn (2008): "The Aggregate Effects of Anticipated and Unanticipated U.S. Tax Policy Shocks: Theory and Empirical Evidence," EUI Working Papers, ECO 2008/05.

New Zealand Treasury (2003): Objectives, Targets and Instruments for Crown Financial Policy. New Zealand Treasury, Wellington.

- (2006): New Zealand's Long-Term Fiscal Position. New Zealand Treasury, Wellington.

(2009): Fiscal Strategy Report. The Treasury, Wellington, May 28. 
Poloz, S., D. Rose, and R. Tetlow (1994): "The Bank of Canada's New Quarterly Projection Model (QPM): An Introduction," Bank of Canada Review, Autumn, 23-38.

PoterbA, J. M. (1988): "Are Consumer Forward Looking? Evidence from Fiscal Experiments," American Economic Review Papers and Proceedings, 78(2), 413-418.

- (1989): "Tax Reform and the Market for Tax-Exempt Debt," Regional Science and Urban Economics, 19(3), 537-562.

Pouzo, D. (2009): "Optimal Taxation with Endogenous Default Under Incomplete Markets," Manuscript, New York University.

Ramey, V. A. (2007): "Identifying Government Spending Shocks: It's All in the Timing," Manuscript, University of California, San Diego.

Ramey, V. A., And M. D. Shapiro (1998): "Costly Capital Reallocation and the Effects of Government Spending," Carneige-Rochester Conference Series on Public Policy, 48, 145-194.

Reinhart, C. M., and M. A. Savastano (2003): "The Realities of Modern Hyperinflation," Finance \& Development, 40(2), 20-23.

Reserve Bank of New Zealand (2004): The Reserve Banks Forecasting and Policy System. Reserve Bank of New Zealand, Wellington.

Romer, C., And J. Bernstein (2009): The Job Impact of the American Recovery and Reinvestment Plan. Obama Transition Team, Washington, D.C., January 9.

Rotemberg, J. J., and M. Woodford (1999): "Interest Rate Rules in an Estimated Sticky Price Model," in Monetary Policy Rules, ed. by J. B. Taylor, pp. 57-119. University of Chicago Press, Chicago.

SaCHS, J. (1987): "The Bolivian Hyperinflation and Stabilization," American Economic Review Papers and Proceedings, 77(2), 279-283.

Sargent, T. J. (1982): "Beyond Supply and Demand Curves in Macroeconomics," American Economic Review Papers and Proceedings, 72(2), 382-389.

(1986): "The Ends of Four Big Inflations," in Rational Expectations and Inflation. Harper \& Row, New York.

Sargent, T. J., And N. Wallace (1981): "Some Unpleasant Monetarist Arithmetic," Federal Reserve Bank of Minneapolis Quarterly Review, 5(Fall), 1-17.

Schmitt-Grohe, S., And M. Uribe (2007): "Optimal Simple and Implementable Monetary and Fiscal Rules," Journal of Monetary Economics, 54(6), 1702-1725.

Scotт, G. (1995): "New Zealand's Fiscal Responsibility Act," Agenda, 2(1), 3-16.

Sims, C. A. (1994): "A Simple Model for Study of the Determination of the Price Level and the Interaction of Monetary and Fiscal Policy," Economic Theory, 4(3), 381-399.

- (2001): "Fiscal Consequences for Mexico of Adopting the Dollar," Journal of Money, Credit and Banking, 20(2, Part 2), 597-616.

(2005): "Limits to Inflation Targeting," in The Inflation-Targeting Debate, ed. by B. S. Bernanke, and M. Woodford, pp. 283-299. The University of Chicago 
Press, Chicago.

- (2008): "Stepping on a Rake: The Role of Fiscal Policy in the Inflation of the 1970's," Manuscript, Princeton University.

Singh, A., A. Belaisch, C. Collyns, P. De Masi, R. Krieger, G. MeredITH, And R. RennhaCK (2005): "Stabilization and Reform in Latin America: A Macroeconomic Perspective on the Experience Since the Early 1990s," International Monetary Fund Occasional Paper No. 238.

Smets, F., And R. Wouters (2003): "An Estimated Dynamic Stochastic General Equilibrium Model of the Euro Area," Journal of the European Economic Association, 1(5), 1123-1175.

— (2007): "Shocks and Frictions in U.S. Business Cycles: A Bayesian DSGE Approach," American Economic Review, 97(3), 586-606.

Steigerwald, D. G., And C. Stuart (1997): "Econometric Estimation of Foresight: Tax Policy and Investment in the United States," Review of Economics and Statistics, 79(1), 32-40.

Svensson, L. E. O. (1999): "Inflation Targeting as a Monetary Policy Rule," Journal of Monetary Economics, 43(3), 607-654.

Sveriges Riksbank (2007): Monetary Policy Report, vol. 1. Sveriges Riksbank, Stockholm.

— (2008): Monetary Policy in Sweden. Sveriges Riksbank, Stockholm.

(2009): "Minutes of the Executive Boards Monetary Policy Meeting on 1 July 2009," Sveriges Riksbank, July 16, http://www.riksbank.com/templates/Page.aspx?id=32162.

Swedish Fiscal Policy Council (2008): "Swedish Fiscal Policy: Report of the Swedish Fiscal Policy Council, 2008," Stockholm, Sweden.

- (2009): "Swedish Fiscal Policy: Report of the Swedish Fiscal Policy Council, 2009," Stockholm, Sweden.

Swedish Ministry OF Finance (2001): "An Account of Fiscal and Monetary Policy in the 1990s," Government Bill 200/01:100 Annex 5, Stockholm.

TAYlor, J. B. (1993): "Discretion versus Policy Rules in Practice," CarneigeRochester Conference Series on Public Policy, 39, 195-214.

— (ed.) (1999): Monetary Policy Rules. University of Chicago Press, Chicago.

ToBin, J. (1974): "Friedman's Theoretical Framework," in Milton Friedman's Monetary Framework, ed. by R. J. Gordon, pp. 77-89. University of Chicago Press, Chicago.

(1980): Asset Accumulation and Economic Activity. University of Chicago Press, Chicago.

Tobin, J., And W. Buiter (1976): "Long-Run Effects of Fiscal and Monetary Policy on Aggregate Demand," in Monetarism: Studies in Monetary Economics, ed. by J. L. Stein, pp. 274-336. North-Holland, Amsterdam. 
U.S. Department of the Treasury (2007): Strategic Plan: Fiscal Years 200\%2012. The Department of the Treasury, Washington, D.C.

VegA, M., And D. Winkelried (2005): "Inflation Targeting and Inflation Behavior: A Successful Story?," International Journal of Central Banking, 1(3), 153-175.

Walsh, C. E. (2003): Monetary Theory and Policy. MIT Press, Cambridge, MA, second edn.

Wetterberg, G. (2009): Money and Power: From Stockholms Bano 1656 to Sveriges Riksbank Today. Sveriges Riksbank in cooperation with Atlantis, Stockholm.

Woodford, M. (1995): "Price-Level Determinacy Without Control of a Monetary Aggregate," Carneige-Rochester Conference Series on Public Policy, 43(December), 1-46.

- (2001a): "Fiscal Requirements for Price Stability," Journal of Money, Credit, and Banking, 33(3), 669-728.

- (2001b): "Monetary Policy in the Information Economy," in Economic Policy for the Information Economy, pp. 297-370. Federal Reserve Bank of Kansas City, Jackson Hole, Wyoming.

- (2003): Interest and Prices: Foundations of a Theory of Monetary Policy. Princeton University Press, Princeton, N.J.

Wyplosz, C. (2005): "Fiscal Policy: Institutions versus Rules," National Institute Economic Review, 191, 64-78.

_ (2008): "Fiscal Policy Councils: Unlovable or Just Unloved?," Swedish Economic Policy Review, 15, 173-192.

YAnG, S.-C. S. (2005): "Quantifying Tax Effects Under Policy Foresight," Journal of Monetary Economics, 52(8), 1557-1568. 